\title{
Dysregulated MicroRNA Fingerprints and Methylation Patterns in Hepatocellular Carcinoma, Cancer Stem Cells, and Mesenchymal Stem Cells
}

OPEN ACCESS

Edited by:

Mojgan Rastegar

University of Manitoba, Canada

Reviewed by:

Kenneth K. W. To,

The Chinese University of

Hong Kong, China

Zong Wei,

Salk Institute for Biological Studies,

United States

*Correspondence:

Nagwa El-Badri

nelbadri@zewailcity.edu.eg

†These authors have contributed equally to this work

Specialty section:

This article was submitted to

Epigenomics and Epigenetics,

a section of the journal

Frontiers in Cell and Developmental

Biology

Received: 25 July 2019

Accepted: 26 September 2019

Published: 17 October 2019

Citation:

Nasr MA, Salah RA, Abd Elkodous M

Elshenawy SE and El-Badri N (2019)

Dysregulated MicroRNA Fingerprints

and Methylation Patterns in

Hepatocellular Carcinoma, Cancer

Stem Cells, and Mesenchymal Stem

Cells. Front. Cell Dev. Biol. 7:229.

doi: 10.3389/fcell.2019.00229

\author{
Mohamed A. Nasr ${ }^{\dagger}$, Radwa Ayman Salah ${ }^{\dagger}$, M. Abd Elkodous, Shimaa E. Elshenawy and \\ Nagwa El-Badri*
}

Center of Excellence for Stem Cells and Regenerative Medicine (CESC), Zewail City of Science and Technology, 6th of October City, Egypt

Hepatocellular carcinoma (HCC) is one of the top causes of cancer mortality worldwide. Although HCC has been researched extensively, there is still a need for novel and effective therapeutic interventions. There is substantial evidence that initiation of carcinogenesis in liver cirrhosis, a leading cause of HCC, is mediated by cancer stem cells (CSCs). CSCs were also shown to be responsible for relapse and chemoresistance in several cancers, including HCC. MicroRNAs (miRNAs) constitute important epigenetic markers that regulate carcinogenesis by acting post-transcriptionally on mRNAs, contributing to the progression of HCC. We have previously shown that co-culture of cancer cells with mesenchymal stem cells (MSCs) could induce the reprogramming of MSCs into CSC-like cells. In this review, we evaluate the available data concerning the epigenetic regulation of miRNAs through methylation and the possible role of this regulation in stem cell and somatic reprogramming in HCC.

Keywords: miRNA, cancer stem cell, methylation, mesencymal stem cells, hepatocellular carcinoma

\section{HEPATOCELLULAR CARCINOMA}

Hepatocellular carcinoma (HCC) is the most frequent primary malignancy of the liver. It is the third leading cause of mortality associated with cancer worldwide (Yang and Roberts, 2010; Dhanasekaran et al., 2012). HCC is a multifactorial disease that is influenced by several risk factors. It typically develops as a result of underlying liver disease and is commonly associated with cirrhosis (Huang et al., 2013). The major HCC-risk factors include viral infection with hepatitis $\mathrm{B}$ virus (HBV) and hepatitis $\mathrm{C}$ virus (HCV), which leads to liver cirrhosis and accounts for $75 \%$ of HCC cases (El-Serag, 2002). Other factors attributed to HCC include alcohol abuse, intake of food contaminated with aflatoxin and toxic chemical exposure, including dimethylformamide, dimethylacetamide, trichloroethylene, tetrachloroethylene, carbon tetrachloride and chloroform (Malaguarnera et al., 2012). In addition, Obesity is one of the highly recent factors that plays a significant role in developing non-alcoholic fatty liver disease (NAFLD) (Cholankeril et al., 2017). It can progress in many stages starting with lipid deposition in hepatocytes' cytoplasm and can lead to non-alcoholic steatohepatitis (NASH) (Marrero et al., 2002; Guzman et al., 2008; Reddy et al., 2012; White et al., 2012). NASH is the severe stage of NAFLD indicated by hepatocyte injury, uncontrolled inflammation, hepatocyte ballooning, cell death, infiltration of inflammatory cells, 
and collagen deposition (Guzman et al., 2008; Reddy et al., 2012). NASH has been determined to be one of the important events in promoting hepatic carcinogenesis (Ip and Wang, 2014).

Tissue damage and fibrosis result from chronic inflammation and oxidative stress, leading to cirrhosis and eventually tumor initiation, progression, and even metastasis (Lau and Lai, 2008; Shariff et al., 2009; Cabrera and Nelson, 2010). Although only $\sim 10-20 \%$ of HCC patients are eligible for surgical interference at the time of diagnosis, liver transplantation remains the first choice for treatment (Ji et al., 2009a). Furthermore, patients suffer a high frequency of relapse, and in patients who experience curative resection, the 5-year survival rate is $30-40 \%$ (Budhu et al., 2008). The low detection and high recurrence rates for the curable stages of HCC have increased interest in investigations of the molecular mechanisms underlying this disease (He et al., 2015).

\section{CANCER STEM CELLS (CSCS)}

The failure of conventional treatments to completely eliminate invasive tumor cells is thought to be due to the presence of a small subset of cancer cells, termed CSCs, which are accountable for cancer progression, metastasis, recurrence, and drug resistance. CSCs have been classified as immortal tumor-initiating cells which have pluripotent and self-renewal capacity (Chen et al., 2013). CSCs have been identified in numerous solid tumors, such as breast cancer, colon cancer, and HCC (Szotek et al., 2006; O’Brien et al., 2007; Kawai et al., 2015). CSCs were found to have a main contribution in tumor heterogeneity and to contribute to drug resistance (Beck and Blanpain, 2013; Bedard et al., 2013; Klein, 2013; Meacham and Morrison, 2013). While the origin of CSCs remains unclear, the proposed mechanisms for their generation include cell fusion, genetic mutations in stem cells, and regulatory factors within the tumor microenvironment (TME) (Bu and $\mathrm{Cao}, 2012$ ). In addition, signaling pathways and genes that regulate stem cell differentiation, as $\mathrm{Wnt} / \beta$ catenin, transforming growth factor $\beta$ (TGF- $\beta$ ), and microRNAs (miRNAs), could contribute to the control and maintenance of CSC differentiation (Bedard et al., 2013; Meacham and Morrison, 2013). The $\mathrm{Wnt} / \beta$-catenin signaling pathway seems to play major roles in the development of CSCs and in self-renewal, tumorigenesis, and cancer chemoresistance (Espada et al., 2009; Eaves and Humphries, 2010; Mohammed et al., 2016).

\section{CHARACTERISTICS OF MIRNAS}

MiRNAs are small non-coding RNA molecules consisting of 21-23 nucleotides. They control gene expression by base pairing with the messenger RNAs (mRNAs) (Lu et al., 2005; Griffiths-Jones et al., 2006). Transcripts are regulated through either degradation or translational repression (Bartel, 2004). Full complementarity between a miRNA and an mRNA results in full degradation of the target mRNA. However, defects in perfect complementarity leads to less translation of the target gene without affecting the level of mRNA (Lewis et al., 2005; Cummins and Velculescu, 2006). MiRNAs target up to $90 \%$ of human genes (Miranda et al., 2006) and can be found in exons or introns of coding or non-coding genes, with their transcription dependent on genomic localization (Baskerville and Bartel, 2005; Lin et al., 2006). Although miRNAs have their own promoters and are self-sufficiently expressed some miRNAs that share the same transcriptional regulation are ordered in clusters. Hundreds of miRNAs have been known by molecular cloning and bioinformatics approaches in plants and animals (Bushati and Cohen, 2007; Liu et al., 2014). Interestingly, a subgroup of miRNAs, namely, epi-miRNAs, control the expression of epigenetic marks, such as DNA methyltransferases (DNMTs), histone deacetylases (HDACs), and polycomb genes, either directly or indirectly. DNA methylation has a key role in gene expression regulation via maintaining the stability of gene silencing. In mammals, DNA methylation takes place by covalent modification of cytosine residues through the addition of a methyl group to the fifth position of a cytosine ring, particularly in the $\mathrm{CpG}$ dinucleotides. This process is mediated by members of the DNMTs enzymes family (Chuang and Jones, 2007). Therefore, miRNAs function as both genetic and epigenetic regulators (Valeri et al., 2009).

miRNAs control many cellular processes in eukaryotes, such as rate of growth, development, differentiation potential, cell cycle progression, and apoptosis, and their abnormal expression affects many human diseases (Valeri et al., 2009; Krol et al., 2010; Wahid et al., 2010; Pritchard et al., 2012). In addition to serving as essential players in tumor development, miRNAs have a role as possible biomarkers for cancer (Calin and Croce, 2006). Indeed, miRNA profiles reflect the stages of tumors and their developmental lineages (George and Mittal, 2010). MiRNAs have been found to modulate CSCs and metastasis. They can also act as oncogenes and tumor suppressors. Due to their functions as oncogenes and tumor suppressor genes, these miRNAs have been referred to as oncomirs (George and Mittal, 2010).

\section{miRNAs AND HCC}

Recent studies on liver miRNAs investigated the overexpression of specific miRNAs or the inhibition of other miRNAs both in vitro and in vivo. These studies showed the crucial biological roles of miRNAs for proper liver function (Takata et al., 2013). In HCC, Murakami et al. initially reported dysregulated miRNA expression, with four miRNAs, namely, miR-18, miR92, miR-20, and precursor miR-18 being inversely associated with the extent of HCC development (Murakami et al., 2006). Later, several studies confirmed that miRNAs play an essential regulatory role in hepatic carcinogenesis progression and malignant transformation. Some miRNAs showed abnormal expression during the progression of liver cancer (Zhao et al., 2009). The expression of some miRNAs was shown to influence HCC development via dysregulation of a number of cancerassociated molecular pathways, including TGF- $\beta, p 53, W N T / \beta$ catenin, P13K/AKT/mTOR, RAS/MAPS, MET, and MYC (Negrini et al., 2011). Many oncogenic miRNAs have shown aberrant expression in HCC, including miR-1275 (Shaalan et al., 2018), miR-17-5p (Habashy et al., 2016), miR-96-5p, miR-182-5p (Assal 
et al., 2015), miR-155 (El Tayebi et al., 2015), and miR-181a (Lashine et al., 2011). Other tumor suppressor miRNAs involved in HCC include miR-34a (Yacoub et al., 2016), miR-486-5p (Youness et al., 2016), miR-615-5p (El Tayebi et al., 2012), and miR-Let7i (Fawzy et al., 2016). Genome-wide approaches have identified hundreds of miRNAs in HCC tumor tissues that were to be dysregulated compared to non-tumor tissues (Borel et al., 2012). MiR-122 is among many unique and well-studied dysregulated miRNAs that are highly expressed specifically in human liver. In HCC patients, a shorter recurrence time were attributed to lower levels of miR-122. While elevated expression of cyclin G1, a target of miR-122, was associated with a lower survival rate. Moreover, miR-122 acts as a tumor suppressor in HCC, and was subsequently reported to be downregulated in around 70\% of cases (Callegari et al., 2013). MiR-221 is another critical oncogenic miRNA that is upregulated in $70-80 \%$ of HCC cases. Its overexpression leads to enhanced proliferation potential, migration, invasion, rate of growth, and decreased the rate of apoptosis in HCC patients (Fornari et al., 2008). Additionally, miR-221 modulates several gene targets involved in cancer-related pathways, including PTEN ( $P 13 K / A K T / m T O R)$, $C D K N 1 B / p 27$, and CDKN1C/p57 (Fornari et al., 2008; Garofalo et al., 2009).

Due to their non-invasive detection, good specificity, and sensitivity, miRNAs are considered effective biomarkers for HCC (Shen et al., 2016). MiR-155-5p, miR-206, miR-21-5p, and miR-212-3p. MiR-155-5p and miR-21-5p which are reported as biomarkers for the prognosis of HCC in tissues, were found to have upregulated expression levels. On the other hand others were down-regulated (Han et al., 2013; Wang et al., 2014; Yunqiao et al., 2014; Tu et al., 2015). Circulating miR-122-5p and miR-16-5p could be used as presumed biomarkers for HCC. MiR-122-5p and miR-16-5p belong to this group which were particularly detected to be up and down-regulated, respectively (Cho et al., 2015; El-Abd et al., 2015).

Most often, elevated expression of miR-18b-5p, miR-200a-3p, miR-200b-3p, miR-21-5p, miR-224-5p, and miR-29-5p in tissue were mostly reported to be HCC. In addition, miR-139-5p was down-regulated. Therefore, they were beneficial for diagnosis of HCC (Zhu et al., 2012; Murakami et al., 2013; Dhayat et al., 2014; Han et al., 2014; Li T. et al., 2014; Amr et al., 2016).

Circulating miRNAs were proposed as prognostic biomarkers and reported to be linked to tissue invasion and metastasis. Those biomarkers included miR-122-5p, miR-17-5p, miR-182-5p, miR21-5p, miR-24-3p, and miR-331-3p, all were up-regulated in the group reported to have a low-survival rate (Zheng et al., 2013; Meng et al., 2014; Chen et al., 2015; Wang L.-J. et al., 2015; Xu Y. et al., 2015). Meanwhile, the serum miR-150-5p was highly expressed in HCC patients after surgical operation, however following tumor relapse its expression levels were reversed (Yu F. et al., 2015).

In tissues, high expression of miR-150-5p and miR-29a$5 p$ in combination of low expression of miR-101-3p, miR126-3p, miR-127-3p, miR-139-5p, and miR-214-3p have tumorsuppressor roles and consequently have potential use as diagnostic biomarkers for HCC (Zhu et al., 2012; Han et al., 2014; Li T. et al., 2014; Peveling-Oberhag et al., 2014; Xie et al., 2014;
Zhou et al., 2014; Wang S. et al., 2015). The association between the circulating miR-101-3p, miR-122-5p, miR-125b-5p, miR139-5p, miR-150-5p, miR-16-5p, miR-181a-5p, miR-199a-3p, miR-199a-5p, miR-203a-3p, miR-21-5p, miR-22-3p, miR-29b-3p, miR-375, let-7b-5p, and tumor suppressor render them potential biomarkers for differentiating HCC from healthy controls (Zhou J. et al., 2011; Luo et al., 2013; Li T. et al., 2014; Tan et al., 2014; Xie et al., 2014; Chen et al., 2015; Jiang et al., 2015; Wang S. et al., 2015; Yin et al., 2015; Yu F. et al., 2015; Hung et al., 2016). Contrarily, miR-101-3p, miR-122-5p, miR-125b-5p, miR-130a$3 p$, miR-146a-5p, miR-214-3p, and miR-99a-5p were known as tumor suppressors in HCC and played the role of prognostic indicators for HCC (Zhang et al., 2012; Wang et al., 2013; Li B. et al., 2014; Rong et al., 2014; Tsang et al., 2014; Xie et al., 2014; Xu Q. et al., 2015). Serum miR-1-3p, miR-101-3p, miR-122-5p, miR-150-5p, miR-203a-3p, and miR-30c-5p were linked to tumor suppression, and new independent parameters of overall survival in HCC (Köberle et al., 2013; Xie et al., 2014; Cho et al., 2015; Liu D. et al., 2015; Xu Y. et al., 2015; Yu F. et al., 2015).

As miRNAs expression levels can be used as biomarkers for HCC diagnosis and prognosis, miRNA specific methylation patterns are of importance for therapeutic applications as well. Acting as a tumor suppressor miRNA, decreased expression of miR-10a due to hypermethylation can be used as a biomarker for early HCC diagnosis and risk assessment (Shen et al., 2012). Furthermore, some miRNAs methylation patterns can be HCC cell-specific and therefore used as diagnostic biomarkers. Such miRNAs cell-specific diagnostic methylation patterns include the hypermethylation of miR-129-2, miR-34a, and miR-148a (Anwar et al., 2013; Lu et al., 2013). Also, hypermethylation of mir-9-1 has been shown to be a biomarker for poor diagnosis and aggressiveness (Anwar et al., 2013). In addition to their implications in diagnosis and prognosis, miRNA specific aberrant methylation patterns can be used for therapeutic applications. For example, administration of miR-124, which is hypermethylated in HCC, stopped HCC progression in animal models and was considered safe. Moreover, sorafenib (anticancer drug) increased the expression of miR-1274, which is hypermethylated in HCC, leading to an increased response to therapy (Zhou C. et al., 2011).

\section{miRNAs AND CSCs IN HCC}

miRNAs play essential roles in regulating CSCs (Garg, 2015), and in regulating apoptosis in CSCs by acting on mRNAs of apoptosis proteins or regulating mRNAs that are downstream targets in specific apoptotic pathways. These control mechanisms aid in the regulation of metastasis, drug resistance, tumor invasion, pluripotency, and self-renewal potential.

The tumorigenicity of liver CSCs was found to be significantly suppressed by inhibition of miR-181. This miRNA regulates the differentiation potential of liver CSCs through activating transcription factors, including caudal homeobox gene 2 (CDX2) and GATA6, and negatively regulating the $\mathrm{Wnt} / \beta$-catenin pathway via nemo-like kinase (NLK) (Ji et al., 2009b; Leal and Lleonart, 2013; Bessède et al., 2014). MiR-Let-7 and 
miR-Lin28 have been reported to be related to the rate of growth and metastasis of HCC. Lin 28 is highly expressed in normal embryonic stem cells (ESCs). It maintains the selfrenewal of liver CSCs by inhibiting the interaction of Let-7 with the mature miRNA. Let-7 degradation, which is caused by excessively active Lin28 and c-MYC, dis-equilibrates liver CSCs, leading to accelerated growth and metastasis of HCC (Heo et al., 2008). MiRNAs positively regulate liver CSCs via high expression of EpCAM, which is a prominent marker of liver CSCs. This upregulation is mediated by inhibition of TGF- $\beta$ by downstream transcription factors of miR-18, such as CDX2, GATA6, and NLK. The EpCAM intracellular domain (EpICD) enters the nucleus and induces overexpression of cyclin D1, c-MYC, and miR-181 after binding to LIM domain protein 2 (FHL2), $\beta$-catenin and lymphoid enhancer factor 1 (Lef-1) (Ji et al., 2009b). Another group showed that TGF- $\beta 1$ downregulate TP53INP1 by targeting miR-155 and promote epithelial-mesenchymal transition (EMT) and liver CSC phenotypes (Liu F. et al., 2015). The Wnt/ $\beta$ catenin signaling pathway that regulates tumor heterogeneity is mainly related to miRNA, but the mechanism by which this balance between liver CSCs and cancer cells is maintained has not been elucidated.

Based on previous studies, some miRNAs expression was reported to be dysregulated in both HCC and CSCs. In Table 1, we compiled the mutually dysregulated miRNAs to establish the links between these miRNAs and the initiation and progression of HCC.

We classified the previously reported miRNAs as mutually upregulated, mutually downregulated, and mutually dysregulated but not mutually upregulated or mutually downregulated, as illustrated in Figure 1.

A schematic presentation of the role of dysregulated miRNAs in HCC initiation, progression, and aggressiveness is presented in Figure 2.

As reported previously, MSCs aid in cancer development by enhancing the metastatic capability of tumor cells (Hill et al., 2017). This has been also reasoned by the fact that MSCs can home to tumor microenvironment mainly due to the action of stromal cell-derived factor 1 (SDF-1) (Gao et al., 2009). After homing, MSCs start to trans-differentiate into cancer associated fibroblasts mainly due to the action of TGF-betal (Ghaderi and Abtahi, 2018). Afterwards, cancer associated fibroblasts (CAFs) start to induce metastasis in neighboring tumor cells by inducing EMT (Wang et al., 2018). Some of the significant genes involved in such pro-metastatic signature of the tumor MSCs have been identified in lung cancer and they include GREM1, LOXL2, ADAMTS12, and ITGA11 (Fregni et al., 2018). Also, as investigated by our research group, soluble factors secreted from cancer cells when cocultured with MSCs have shown to induce cancer stem cell-like characteristics in the cocultured MSCs (ElBadawy et al., 2017). Relating the previous information, we are trying to highlight the mutual dysregulated miRNA in HCC, CSCs, and MSCs to investigate whether miRNAs play a vital role in the acquirement of MSCs to pro-metastatic characteristics or development into Cancer stem cells- like cells or even CAFs. So, in Table 2, we summarize the roles of miRNAs that are mutually dysregulated in HCC, CSC, and in MSCs. The functions of these miRNAs may provide insight into their regulatory roles in the development of cancer (Schraivogel et al., 2011). Based on these proposed functions (Table 2), we classified these miRNAs according to their roles in MSC differentiation.

Figure 3 shows the potential pathways that may be involved in the reprogramming of MSCs and their acquisition of CSC-like characteristics after co-culture with cancer cells.

The relationship between the expression of miRNAs expression, their target genes' expression, and the fate of HCC is detailed in Table 3.

\section{DYSREGULATED MIRNA METHYLATION IN HCC}

Genome-wide abnormal DNA methylation of miRNA host genes in HCC was recently reported. One study analyzed tumor and neighboring normal non-tumor tissues in 62 HCC patients. This analysis was performed using Infinium Human Methylation Analysis Bead Chips. One hundred ten miRNAs from 64 different host genes were covered in this analysis through assessing the methylation of $254 \mathrm{CpG}$ sites. Methylation levels were found to be significantly different at $54 \mathrm{CpG}$ sites from 27 host genes between tumor and neighboring normal non-tumor tissues (Shen et al., 2012). In addition, the expression of three identified miRNAs were measured. MiR-10a was downregulated in tumor tissues and therefore its action on its oncogenic target genes as a tumor suppressor miRNA diminished. This decline appeared to be related to hypermethylation of the host genes. Accordingly, aberrant methylation and expression of miRNAs were considered valuable molecular biomarkers for HCC early diagnosis (Shen et al., 2012). In another study, miRNA genes, from HCC cells and normal liver hepatocytes, showed significantly different profiles of global DNA methylation. In the same study, in HCC cells, miRNAs CpG-poor regions were more commonly hypomethylated rather than being hypermethylation ( $\mathrm{He}$ et al., 2015). Investigations using miRNA expression microarray data identified 10 dysregulated miRNAs in HCC that are regulated by DNA methylation. Of the 10 studied miRNAs, miR-23a/27a and miR-25/93/106b constituted two miRNA clusters in which five miRNAs were upregulated. On the other hand, the other five miRNAs including miR-375, miR-195, miR-497, miR-378, and miR-148a were downregulated (He et al., 2015). The cluster containing miR-25/93/106b, with upregulated expression, was required for cell proliferation including the anchorageindependent growth. It was also shown to target the E2F1 transcription factor in HCC, which inhibits apoptosis (Li Y. et al., 2009). Additionally, miR-331-3p was shown to target PHLPP, a protein that plays a central role in inducing apoptosis and reducing metastasis (Ma et al., 2010; Liu J. et al., 2011; Chang et al., 2014; Peuget et al., 2014). These data provide further evidence for the potential role of miR-331-3p in HCC metastasis. The miR-23a/27a cluster, with upregulated expression, enhanced anti-apoptotic pathways in addition to promoting cells proliferation in HCC (Huang et al., 2008). In another study, miR-429 functioned by manipulating liver 
TABLE 1 | miRNAs whose expression was reported to be dysregulated in HCC and CSCs.

\begin{tabular}{|c|c|c|}
\hline miRNA & Expression and biological function in HCC & Expression and biological function in CSCs \\
\hline miR-Let-7a & $\begin{array}{l}\text { Downregulated (Connolly et al., 2008) } \\
\text { MiR-Let-7 family act as tumor suppressors via regulating expression of } \\
\text { oncogenes including RAS, COL1A2, and AT-hook } 2 \text { high mobility group } \\
\text { (Johnson et al., 2005; Shi et al., 2017) }\end{array}$ & $\begin{array}{l}\text { Downregulated (Yata et al., 2015) } \\
\text { The let-7 miRNA family has been reported to maintain the state of } \\
\text { differentiation and self-renewal inhibition of CSCs by targeting Lin28, } \\
\text { H-RAS, and HMGA2 (Ali Hosseini Rad et al., 2013; Sun et al., 2016) }\end{array}$ \\
\hline $\begin{array}{l}\text { miR-Let-7b } \\
\text { miR-Let-7c } \\
\text { miR-Let-7d } \\
\text { miR-Let-7e } \\
\text { miR-Let- } \\
7 f \text { miR-Let-7g }\end{array}$ & $\begin{array}{l}\text { Downregulated (Gramantieri et al., 2007) } \\
\text { Act as tumor suppressors by targeting mRNA of RAS, COL1A2, and } \\
\text { AT-hook } 2 \text { group }\end{array}$ & $\begin{array}{l}\text { Downregulated (Peter, 2009) miR-Let-7 family is involved in the } \\
\text { differentiation of CSCs and maintenance of stemness by targeting Lin28 } \\
\text { which have a negative effect on Let-7, and inhibits the expression of } \\
\text { H-RAS and HMGA2 (Ali Hosseini Rad et al., 2013) }\end{array}$ \\
\hline miR-9 & $\begin{array}{l}\text { Upregulated (Wang et al., 2008) } \\
\text { MiR-9 increases growth and metastasis (Chen et al., 2015). It targets } \\
\text { directly the 3'UTR of PPAR alpha and regulates its expression levels in liver } \\
\text { cancer cells. MiR-9 is highly over expressed in liver cancer patients. It acts } \\
\text { as tumor suppressor, and could have a therapeutic effect (Chen et al., } \\
2015 \text { ) }\end{array}$ & $\begin{array}{l}\text { Upregulated (Schraivogel et al., 2011) } \\
\text { miR-9 is responsible for maintaining stemness and promotion of CD 133+ } \\
\text { cell proliferation by targeting CAMTA } 1 \text { (Takahashi et al., 2014; Wang L.-J. } \\
\text { et al., 2015) }\end{array}$ \\
\hline $\operatorname{miR}-16$ & $\begin{array}{l}\text { Upregulated (Huang et al., 2009) } \\
\text { MiR-16 targets and regulates } \mathrm{Bcl}-2 \text { and suppresses } \mathrm{Bcl}-2 \text { protein } \\
\text { expression by binding to the 3'UTR of Bcl-2 mRNA. Bcl-2 is one of the } \\
\text { well-known anti apoptotic protein members in Bcl-2 family that control } \\
\text { cancer cells response to drugs (Wang et al., 2018). RHepG2 cells, the } \\
\text { multidrug resistant subgroup of human HCC HepG2 cells were reported to } \\
\text { have higher levels of miR-16 and P-glycoprotein which is associated with } \\
\text { multidrug resistance and lower level of Bcl-2 (Fregni et al., 2018) }\end{array}$ & $\begin{array}{l}\text { Upregulated (Caruso et al., 2012) } \\
\text { miR-16 regulates proliferation and self-renewal by targeting bmi1 (B } \\
\text { lymphoma Mo-MLV insertion region } 1 \text { homolog) (Shimono et al., 2015) }\end{array}$ \\
\hline $\operatorname{miR}-17$ & $\begin{array}{l}\text { Upregulated (Huang et al., 2009) } \\
\text { The miR-17-92 cluster is the first oncogenic miRNAs identified in human } \\
\text { (El-Badawy et al., 2017). This cluster targets thrombospondin-1 (TSP1), } \\
\text { proangiogenic targets, and connective tissue growth factor (CTGF) to } \\
\text { increase the potential of tumor angiogenesis (Sung et al., 2013) }\end{array}$ & $\begin{array}{l}\text { Upregulated (Schraivogel et al., 2011) } \\
\text { Promotion of CD } 133^{+} \text {cell proliferation by targeting CAMTA } 1 \text { (Takahashi } \\
\text { et al., 2014) }\end{array}$ \\
\hline miR-20a & $\begin{array}{l}\text { Upregulated (Connolly et al., 2008) } \\
\text { Involved in proliferation and recurrence of HCC (Zheng et al., 2013). } \\
\text { MiR-20 a reduced the endogenous level of myeloid cell leukemia sequence } \\
\text { 3'UTR Mcl-1 protein in HCC (Liu et al., 2012) }\end{array}$ & $\begin{array}{l}\text { Upregulated (Caruso et al., 2012) } \\
\text { Regulating and enhancing stemness properties (Yu F. et al., 2015) }\end{array}$ \\
\hline $\mathrm{miR}-21$ & $\begin{array}{l}\text { Upregulated (Connolly et al., 2008) } \\
\text { Involved in progression and metastasis (Xie et al., 2014). miR-21 inhibited } \\
\text { KLF5 gene by targeting its } 3^{\prime} \text {-UTR. KLF5 gene play a role in cancer as a } \\
\text { tumor inhibitor (Wang et al., 2012) }\end{array}$ & $\begin{array}{l}\text { Upregulated (Caruso et al., 2012) enhance stemness properties of CSCs } \\
\text { by targeting TGF } \beta \text { R2 (Ali Hosseini Rad et al., 2013) }\end{array}$ \\
\hline miR-24 & $\begin{array}{l}\text { Upregulated (Huang et al., 2009) } \\
\text { Has a role in metastasis and invasion (Zhou et al., 2014) miRNA-24 binds } \\
\text { to the } 3^{\prime} \text {-UTR of p53 mRNA and down regulates its expression }\end{array}$ & $\begin{array}{l}\text { Upregulated (Roscigno et al., 2017) } \\
\text { Involved in maintaining stemness markers } \\
\text { It has been postulated that miR-24 survived stem cells from apoptosis in } \\
\text { the hypoxia conditions through an FIH1-HIF } \alpha \text { pathway as it have HIF } \\
\text { binding site (Peveling-Oberhag et al., 2014) }\end{array}$ \\
\hline $\operatorname{miR}-27 a$ & $\begin{array}{l}\text { Upregulated (Connolly et al., 2008) } \\
\text { MiRNA-2a regulates PPAR- } \gamma \text { expression through promoting HCC } \\
\text { cell proliferation }\end{array}$ & $\begin{array}{l}\text { Upregulated (Caruso et al., 2012) } \\
\text { Promotes angiogenesis and metastasis through targeting ENPP1 } \\
\text { (Shimono et al., 2015) }\end{array}$ \\
\hline miR-29c & $\begin{array}{l}\text { Downregulated (Su et al., 2009) } \\
\text { miR-29c targets SIRT1 oncogene thus acting as a tumor suppressor } \\
\text { (Hung et al., 2016) }\end{array}$ & Upregulated (Caruso et al., 2012) \\
\hline miR-96 & $\begin{array}{l}\text { Upregulated (Wang et al., 2008) } \\
\text { MiR-96 over expression targets SOX6 that regulates proliferation potential, } \\
\text { invasion and migration (Liu Y. et al., 2011) }\end{array}$ & Downregulated (Shimono et al., 2015) \\
\hline $\operatorname{miR}-34 a$ & $\begin{array}{l}\text { Downregulated (Sun et al., 2017; Xia et al., 2017; Ren et al., 2018) } \\
\text { Involved in inhibition of invasion and migration potential Through c-Met } \\
\text { signaling pathway (Rong et al., 2014) miR-34a targeted c-Met resulting in } \\
\text { decreasing the mRNA and protein levels; thus, decrease phosphorylation } \\
\text { of extracellular signal-regulated kinases } 1 \text { and } 2 \text { (Li N. et al., 2009) }\end{array}$ & $\begin{array}{l}\text { Downregulated (Wheeler et al., 2009; Stadler et al., 2010) } \\
\text { Involved in inhibiting the self-renewal and metastasis of CSCs (Tsang et al., } \\
\text { 2014) and suppression of asymmetric cell division in CSCs by targeting } \\
\text { NOTCH } 1 \text { (Wang et al., 2013; Takahashi et al., 2014) }\end{array}$ \\
\hline
\end{tabular}


TABLE 1 | Continued

\begin{tabular}{ll}
\hline miRNA & Expression and biological function in HCC \\
\hline miR-93 & Upregulated (Thurnherr et al., 2016) \\
& MiR-93 over expression in-vitro enhanced HCC cell migration and invasion \\
& by targeting Programmed cell death 4 (PDCD4) gene (Zhang et al., 2012) \\
miR-495 & Upregulated (Yang et al., 2013) \\
& miR-495 targets IGFIR and regulates ERK and AKT pathways, therefore \\
& inhibiting invasion and proliferation potential of HCC cells (Kim et al., 2012)
\end{tabular}

$\operatorname{miR}-1246$

Downregulated (El-Halawany et al., 2015)

miR-1246 enhances the cell migration by targeting $3^{\prime}$ UTR of the cell adhesion molecule 1 and downregulating its expression (Ma et al., 2010)

miR-210 Upregulated (Yang et al., 2016)

miR-210 targets SMAD4 and STAT6 to promote tumor angiogenesis (Huang et al., 2008)

$\operatorname{miR}-18$

Upregulated (Liu et al., 2017)

The inhibition of miR-18 enhances the migration of HCC by targeting

Smad2 (Li L. et al., 2015)

miR-191 Upregulated (He et al., 2011)

miR-191 promotes proliferation, tumor growth of HCC cells, and apoptosis

by targeting TIMP3, TMC7, SOX4, and IL1A (Chang et al., 2012)

miR-7 Downregulated (Yu et al., 2016)

miR-7 targets oncogenes such as Cdr 1 and acts tumor suppressor (Lu et al., 2013)

miR-150 Downregulated (Thurnherr et al., 2016)

miR-150 acts as tumor suppressor by inhibiting GAB1 expression and downregulating ERK activation

miR-145 Downregulated (Thurnherr et al., 2016) Downregulated (Thurnherr et al., 2016) miR-145 regulates growth rate and proliferation and the re-expression of miR-145 resulting in cell apoptosis. It has been reported that insulin-like growth factor (IGF) is an important oncogenic pathway in HCC. Meanwhile, miR-145 targets insulin receptor substrate (IRS1)-1, IRS2, and insulin-like growth factor 1 receptor (Law et al., 2012)

miR-101 Downregulated (Su et al., 2009) Involved in promoting apoptosis and suppressing tumorigenicity (Jiang et al., 2015) via targets RAB5A, STMN1, and ATG4D (Xu Y. et al., 2013)

miR-141 Downregulated (Gramantieri et al., 2007)

MiR-141 targets Tiam1 genes and inhibits HCC cells migration, proliferation and invasion potential in-vitro (Schoolmeesters et al., 2009)

miR-142 Downregulated (Gramantieri et al., 2007)

miR-155 Upregulated (Wang et al., 2008)

Enhances proliferation, growth, and tumorigenesis and decreases apoptosis (Gramantieri et al., 2007; Peter, 2009)

miR-183 Upregulated (Wang et al., 2008) Regulates carcinogenesis (Takahashi et al., 2014). MiR-183 suppress apoptosis in HCC cells through targeting Programmed cell death 4 (PDCD4). PDCD4 mediates its proapototic function in human HCC by being involved in the TGF- $\beta 1$-induced apoptotic pathway (Li et al., 2010)

miR-185 Downregulated (Huang et al., 2009)

In HCC: miR-185 induces HCC proliferation by targeting the DNTM1 3'UTR luciferase (Chang et al., 2014)

miR-194 Downregulated (Huang et al., 2009) miR-194 induces apoptosis by targeting MAP4K4 (Peuget et al., 2014)

miR-200a Downregulated (Murakami et al., 2006)

Involved in enhancing proliferation and carcinogenesis (Caruso et al., 2012). Meanwhile, it regulates the invasion and migration of HCC cells by targeting Foxa2 (Chen et al., 2017)

\section{Expression and biological function in CSCs}

Downregulated (Caruso et al., 2012)

Upregulated (Hwang-Verslues et al., 2011)

Enhance stemness properties of CSCs by targeting REDD1 (Ali Hosseini Rad et al., 2013)

Upregulated (Eshelman and Yochum, 2016; Zhang et al., 2016)

Maintains properties of CSCs by targeting Wnt/beta-catenin pathway (Lou et al., 2018)

Upregulated (Bao et al., 2012)

Promotes metastasis, proliferation, and self-renewal of CSCs by targeting

E-cadherin (Tang et al., 2018)

Upregulated (Turchi et al., 2013)

Modulates tumorigenesis (Mens and Ghanbari, 2018)

Upregulated (Xu W. et al., 2015)

Downregulated (Zhang et al., 2014)

Inhibits metastasis by targeting SETDB1 (Shimono et al., 2015)

Upregulated (Liu D. Z. et al., 2015) increases proliferation by targeting Wnt signaling pathway (Shimono et al., 2015)

Downregulated (Yu Y. et al., 2015; Zhou et al., 2017)

Targets ROCK1, Oct-4, Sox2, and Klf 4 genes and inhibits tumorigenesis, invasion, and stemness (Shi et al., 2017)

Upregulated (Caruso et al., 2012)

Downregulated (Gregory et al., 2008) inhibits the proliferation of CSCs by suppressing Wnt signaling pathway (Shimono et al., 2015)

Upregulated (Caruso et al., 2012; Chapnik et al., 2014) Inhibits the proliferation of CSCs by suppressing Wnt signaling pathway (Shimono et al., 2015)

Upregulated (Caruso et al., 2012)

Downregulated (Dambal et al., 2015; Leung et al., 2015)

Maintains EMT and self-renewal of CSCs by targeting SNAI2, SMAD4, and bmi1 (Shimono et al., 2015)

Upregulated (Caruso et al., 2012)

Upregulated (Caruso et al., 2012) maintains self-renewal by targeting bmi1 (Shimono et al., 2015)

Downregulated (Pode-Shakked et al., 2013)

Involved in inhibiting EMT, BMI1, Sox2, Klf4, and Notch signaling, and reducing the stemness properties and mammosphere formation of CSCs by targeting ZEB1 and ZEB 2, SIP1, BMI-1, and Klf4 (Ali Hosseini Rad et al., 2013; Shimono et al., 2015) 
TABLE 1 | Continued

\begin{tabular}{|c|c|c|}
\hline miRNA & Expression and biological function in HCC & Expression and biological function in CSCs \\
\hline miR-200b & $\begin{array}{l}\text { Downregulated (Huang et al., 2009) } \\
\text { Involved in enhancing proliferation and carcinogenesis (Caruso et al., 2012) } \\
\text { miR-200b suppressed the expression of BMl1 and ZEB1, moreover ZEB1 } \\
\text { promotes CD13, CD24, and EPCAM resulting in the upregulation of CD13 } \\
\text { and CD24 so, the miR-200-ZEB1 circuit regulates stemness in HCC and } \\
\text { differentiates between HCC contains CD13+/CD24+ CSCs from EpCAM } \\
\text { + CSCs (Tsai et al., 2017) }\end{array}$ & $\begin{array}{l}\text { Downregulated (Pode-Shakked et al., 2013) } \\
\text { Involved in inhibiting EMT, BMI1, Sox2, Klf4, and Notch signaling, and } \\
\text { reducing the stemness properties of CSCs by targeting ZEB1, SIP1, } \\
\text { Bmi-1, and Klf4 (Ali Hosseini Rad et al., 2013; Shimono et al., 2015) }\end{array}$ \\
\hline miR-214 & $\begin{array}{l}\text { Downregulated (Wang et al., 2008) } \\
\text { MiR-214 acts as a suppressor to HCC by downregulating } \beta \text {-catenin } \\
\text { signaling pathway (Nie et al., 2011) }\end{array}$ & $\begin{array}{l}\text { Upregulated (Zhang et al., 2006) } \\
\text { Maintains properties of CSCS by targeting CTNNB1 (Lou et al., 2018) }\end{array}$ \\
\hline miR-215 & $\begin{array}{l}\text { Downregulated (Su et al., 2009) } \\
\text { miR-215 showed significant upregulation in HCC serum, and thus } \\
\text { functions as a biomarker for early diagnosis in HCC patients miR-215 is } \\
\text { significantly correlated with the important genes in Wnt/ } \beta \text {-catenin pathway } \\
\text { including. } \beta \text {-catenin, APC, and c-myc (Ashmawy et al., 2017) }\end{array}$ & $\begin{array}{l}\text { Upregulated (Caruso et al., 2012) } \\
\text { Acts as tumor suppressor (Ullmann et al., 2019) } \\
\text { Mechanistically, miR-215 targets by a cell cycle-regulated nuclear and } \\
\text { centrosome protein, which suppress the miRNA resulted in the induction of } \\
\text { P53, G2 arrest, and P21 and decrease the proliferation (Song et al., 2010) }\end{array}$ \\
\hline miR-221 & $\begin{array}{l}\text { Upregulated (Huang et al., 2009) } \\
\text { Involved in enhancing proliferation and tumorigenicity (Sun et al., 2017; } \\
\text { Ren et al., 2018) }\end{array}$ & $\begin{array}{l}\text { Upregulated (Shimono et al., 2009) } \\
\text { Promotes progression of CSCs by targeting PTEN (Li et al., 2017) }\end{array}$ \\
\hline miR-222 & $\begin{array}{l}\text { Upregulated (Huang et al., 2009) } \\
\text { Involved in enhancing tumorigenesis (Ren et al., 2018) and increase the } \\
\text { growth rate by targeting the cyclin-dependent kinase inhibitor p27 (Song } \\
\text { et al., 2017) }\end{array}$ & $\begin{array}{l}\text { Upregulated (Shimono et al., 2009) } \\
\text { Promotes progression of CSCs by targeting PTEN (Li et al., 2017) }\end{array}$ \\
\hline $\operatorname{miR}-424$ & $\begin{array}{l}\text { Downregulated (Su et al., 2009) } \\
\text { MiR-424 is involved in tumorigenesis of HCC by suppression of c-Myb. It } \\
\text { directly targets the } 3 \text { UTR of c-Myb and induces inhibition of proliferation } \\
\text { and invasion in HCC cells (Zhang et al., 2011) }\end{array}$ & Downregulated (Yata et al., 2015) \\
\hline $\operatorname{miR}-34 a$ & $\begin{array}{l}\text { Downregulated (Peveling-Oberhag et al., 2014; Xie et al., 2014; Yu F. et al., } \\
\text { 2015) } \\
\text { MiR-34a induces apoptosis of HCC and decreases its proliferation by } \\
\text { targeting the expression of HDAC1. It acts as a 3'UTR to regulate its } \\
\text { expression on HCC cells (Peveling-Oberhag et al., 2014) }\end{array}$ & $\begin{array}{l}\text { Downregulated (Zhou et al., 2014; Wang S. et al., 2015) } \\
\text { Inhibits self-renewal properties of CSCs by targeting CD44 and Notch1 (Ali } \\
\text { Hosseini Rad et al., 2013) }\end{array}$ \\
\hline miR-378 & $\begin{array}{l}\text { Downregulated (Xu Y. et al., 2015) } \\
\text { Rs1076064 (pri-miR-378) variant genotypes contributed to the expression } \\
\text { of the miR-378 in decreasing the risk of HCC (Mei et al., 2013) }\end{array}$ & No data \\
\hline miR-24 & $\begin{array}{l}\text { Upregulated ( } \mathrm{Li} \text { T. et al., 2014) } \\
\text { In HCC: miR-24 regulates oncogenes by binding to 3'-UTR of P53 (Hassan } \\
\text { et al., 2010) }\end{array}$ & $\begin{array}{l}\text { Upregulated (Wang L.-J. et al., 2015) } \\
\text { Promotes apoptosis resistance through regulating BimL (Roscigno et al., } \\
\text { 2017) }\end{array}$ \\
\hline $\operatorname{miR}-29 c$ & $\begin{array}{l}\text { Downregulated (Xu Y. et al., 2015) } \\
\text { In HCC: miR-29c targets oncogenic by binding to 3'UTR in SIRT1 (Sun } \\
\text { et al., 2009) }\end{array}$ & Upregulated (Murakami et al., 2013) \\
\hline
\end{tabular}

tumor-initiating cells to target the RBBP4/E2F1/OCT4 axis and was upregulated in HCC due to four aberrant hypomethylated upstream sites (Li L. et al., 2015).

AEG-1 and ATG7 were found to be targets for miR-375, one of the previously mentioned epigenetically downregulated miRNAs, which makes miR-375 a tumor suppressor miRNA in HCC (Chang et al., 2012; He et al., 2012). When overexpressed, miR-375 inhibited both migration and invasion in HCC ( $\mathrm{He}$ et al., 2012). Cell growth was also inhibited by the action of the miR-195/497, which targeted vital cell cycle regulators, leading to G1 arrest in HCC (Furuta et al., 2013). As reported using a bioinformatics approach, CDK4, which is involved in chemotherapy-mediated tumor cell apoptosis, was predicted to be a potential miR-195 target (Yang et al., 2011). MiR378 suppressed HCC tumor growth, which was originally caused by HBV infection. MiR-378 was found to directly target the insulin-like growth factor 1 receptor (IGF1R) (Li et al.,
2013). IGF2BP1, highly involved in liver cancer progression by promoting metastasis, was reported as an expected miR-378 target (Gutschner et al., 2014). Acting as a tumor suppressor miRNA by targeting c-Met which is an oncogene, miR-148 has also been shown to target DNMT1 in hepatocytes leading to the induction of liver-specific phenotype (Gailhouste et al., 2013). MiR-148a is among the five epigenetically downregulated miRNA by methylation and since DNMT1 and DNMT3B are considered to be two of its targets and responsible for its methylation, miR-148a together with DNMT1 and DNMT3B constitute a positive feedback mechanism which in the case of HCC leads to miR-148a downregulation (Duursma et al., 2008; Pan et al., 2010).

Due to several reports of miRNA hypomethylation in HCC, DNA hypomethylation was shown to play a significant role in miRNA regulation. Moreover, DNA methylation might be responsible for the abnormal expression of these miRNAs. 


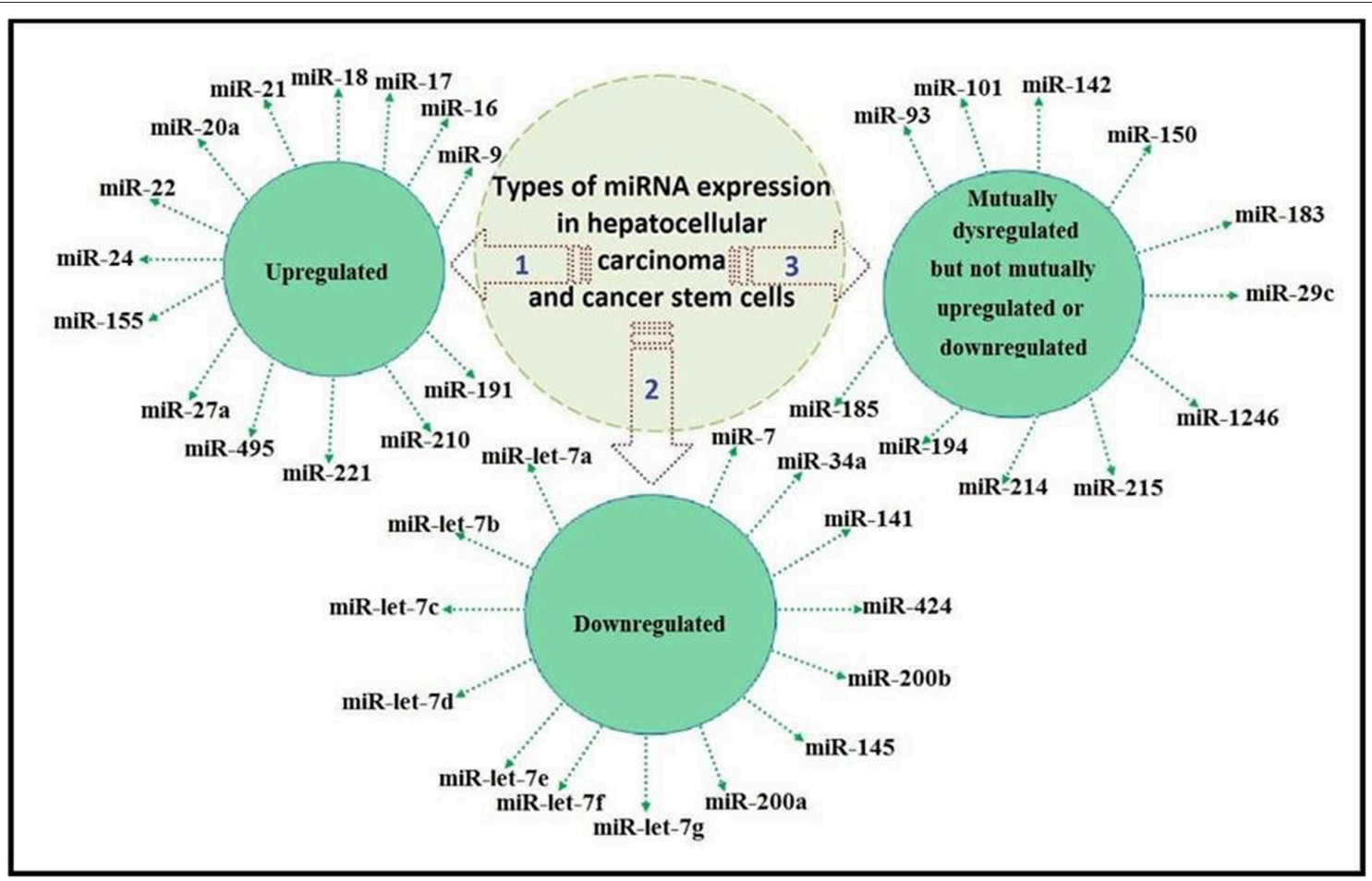

FIGURE 1 | Classification of miRNA expression as mutually upregulated, mutually downregulated, and mutually dysregulated but not mutually upregulated or downregulated.

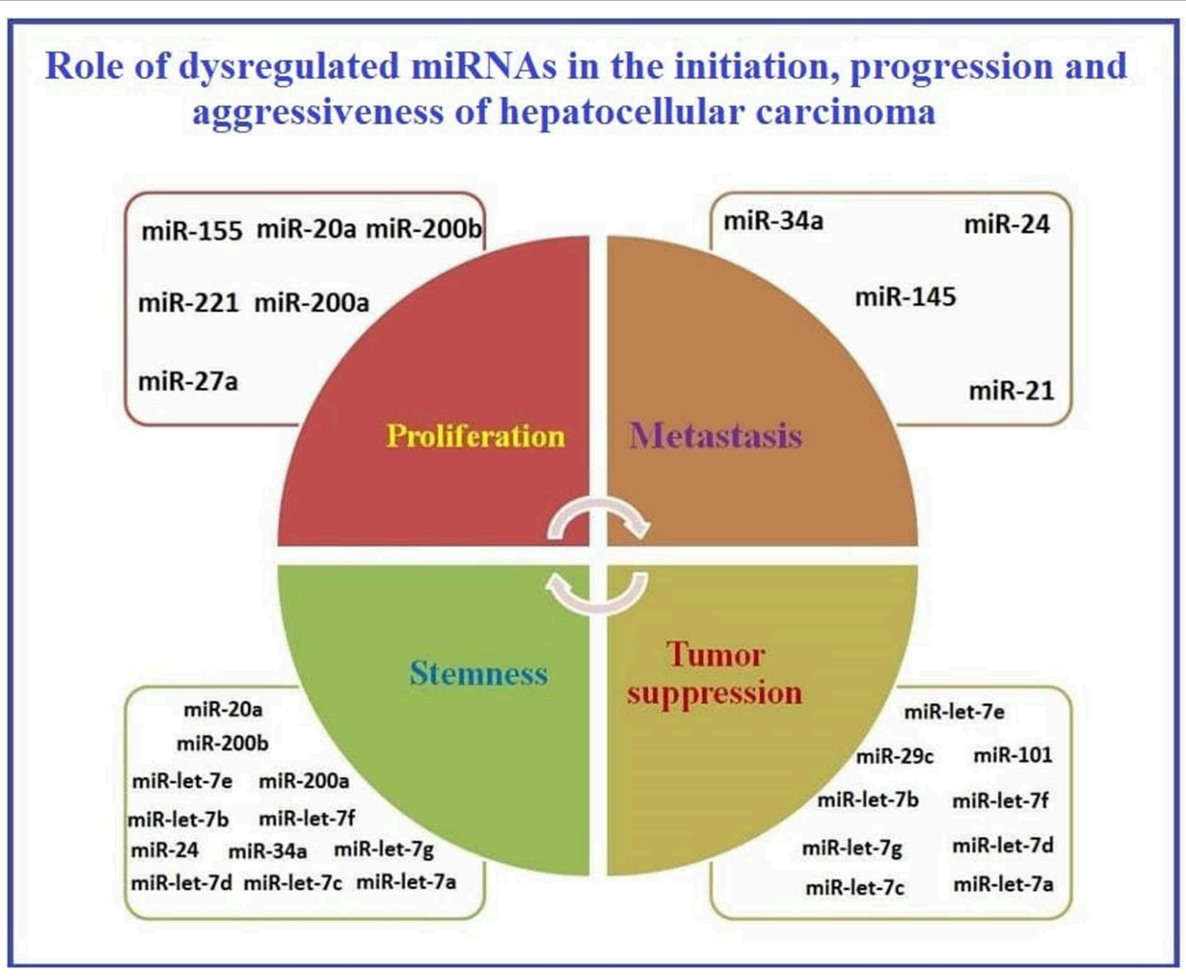

FIGURE 2 | Representation of the role of dysregulated miRNAs in initiation, progression, and aggressiveness of Hepatocellular carcinoma. 
TABLE 2 | The roles of the mutually dysregulated miRNAs in HCC and CSC, in MSC differentiation.

\begin{tabular}{ll}
\hline miRNA & Role in MSCs \\
\hline miR-let-7 family & Inhibits adipogenesis and migration of cells (Sung et al., 2013) \\
miR-16 & Enhances myogenesis and G1 arrest (Liu et al., 2012; Wang \\
& et al., 2012) \\
miR-17 & Enhances osteogenesis (Liu Y. et al., 2011) \\
miR-20a & Enhances osteogenesis (Zhang et al., 2011) \\
miR-21 & Enhances both osteogenesis and adipogenesis but inhibits \\
& proliferation and aids in survival under hypoxic conditions (Nie \\
miR-24 & Et al., 2011; Kim et al., 2012; Mei et al., 2013) \\
miR-27a & 2009; Hassan et al., 2010) \\
miR-141 & Inhibits osteogenesis (Schoolmeesters et al., 2009; Hassan \\
miR-145 & Inhibits osteogenesis (Itoh et al., 2009) \\
miR-222 & Inhibits chondrogenesis (Tong et al., 2011; Martinez-Sanchez \\
miR-155 & et al., 2012) \\
\hline Inhibits adipogenesis and immune regulation (Skårn et al., \\
2012; Xu C. et al., 2013) \\
Inhibits chondrogenesis (Xu et al., 2012) \\
Inhibits osteogenesis (Thurnherr et al., 2016) \\
Inhibits adipogenesis (El-Halawany et al., 2015) \\
\end{tabular}

Accordingly, further studies on these dysregulated miRNAs are needed (He et al., 2015).

In HCC, miRNAs have been shown to be regulated through epigenetic markers, specifically by DNA methylation. In Table $\mathbf{4}$, we review reported methylation-regulated miRNAs in HCC. One of the few studies in this area reported that methylation of miR-203 in CSCs plays a role in EMT and increases cancer progression (Taube et al., 2013). A summary of the available data concerning the epigenetic control of miRNA expression in HCC via methylation is provided in Table 4. Also, Table 4 shows the role the methylation of these miRNAs plays in the progression of HCC.

Data in Table 4 shows some consistent pattern between the role of different miRNAs and their methylation patterns. To illustrate, miRNAs that act as tumor suppressors are hypermethylated while oncomiR are hypomethylated, which finally leads to HCC progression. On the other hand, in HCC, some miRNAs showed an opposite pattern. MiR-10a, miR-10b, miR-9, and miR-196b have been shown to be hypermethylated and their hypermethylation state would lead to reduced tumorigenesis. Therefore, further studies are needed to investigate other roles for these specific miRNAs, and especially the function of miR-596 in HCC progression.

\section{CONCLUSION}

Several studies showed how tumor microenvironment enhances cancer development and progression (Whiteside, 2008; Wang et al., 2017; Klymenko and Nephew, 2018). Studies from our laboratory have shown that soluble HCC factors play a vital

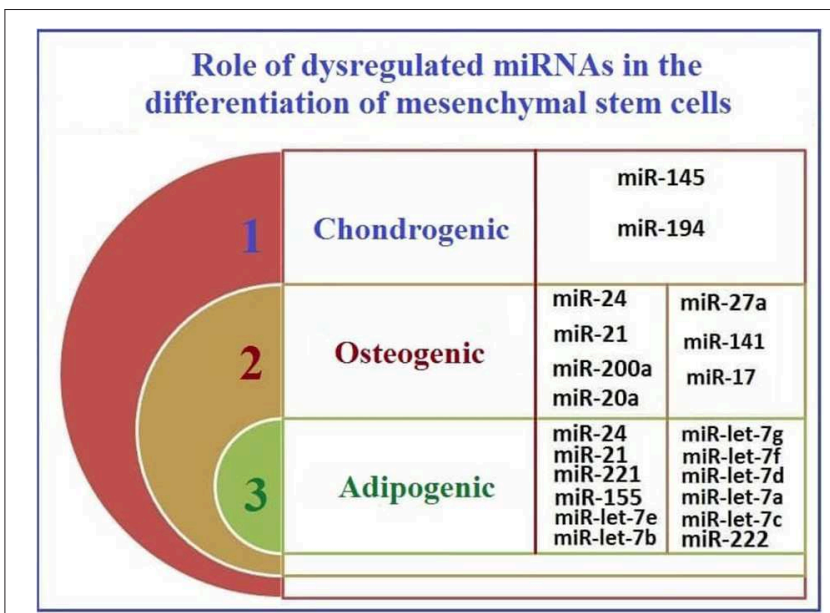

FIGURE 3 | The roles of mutually dysregulated miRNAs in HCC and CSC, in MSC differentiation.

role in the induction of chemoresistance properties in human bone marrow (hBM)-MSCs and trigger their transformation into CSC-like cells (El-Badawy et al., 2017). However, the mechanism of this transformation remains unclear. Although the initiation of HCC is known to be preceded by cirrhosis, the initiation mechanism itself is thought to involve CSCs. CSCs were proposed to be responsible for chemoresistance and relapse in most cancers. Previous data reported by our research group highlighted the role of CSCs in HCC initiation and progression (El-Badawy et al., 2017). Studies also demonstrated that liver CSCs are associated with liver cancer metastasis and relapse and that CSCs play a substantial role in the resistance of liver cancer to conventional treatment (Xu et al., 2009). These data indicate that targeting CSCs as a potential therapeutic approach for liver cancer holds huge promise for improving the treatment outcomes (Lou et al., 2018). Since reprogramming events responsible for the transformation and initiation processes are mainly controlled by epigenetic modifications, determining the role of such epigenetic fingerprints, including miRNAs and their methylation, in initiation, relapse, and chemoresistance in HCC and CSCs is central to understanding tumor biology and developing effective therapies.

Herein, we are presenting growing evidence supporting the central role of miRNAs in many biological processes (Brennecke et al., 2003; Ambros, 2004). In addition, miRNA dysfunction causes the development of diverse cancers (Iorio and Croce, 2009; Negrini et al., 2009). Recent studies show that HCC is associated with altered levels of miRNAs (Murakami et al., 2006; Jiang et al., 2008; Wong et al., 2008). Moreover, several miRNAs, such as miR-195, miR-122, miR-101, and miR-121, have been reported to regulate cell invasion, migration, apoptosis and growth (Fornari et al., 2008; Wang et al., 2008; Su et al., 2009). These findings suggest that dysregulation of miRNA may be attributed to hepatocarcinogenesis (Xiong et al., 2010).

Accumulating data on the expression profiles, roles, and regulation of miRNAs are essential for designing effective stem 
TABLE 3 | The relationship among miRNAs' expression, target genes' expression, and the fate of HCC.

\begin{tabular}{|c|c|c|c|c|}
\hline miRNA & Expression & Target genes & $\begin{array}{l}\text { Expression of target } \\
\text { genes }\end{array}$ & Fate of HCC \\
\hline \multicolumn{5}{|l|}{ miR-Let-7a } \\
\hline \multicolumn{5}{|l|}{ miR-Let-7b } \\
\hline \multicolumn{5}{|l|}{ miR-Let-7c } \\
\hline miR-Let-7d & & RAS oncogenes & & Suppression \\
\hline \multicolumn{5}{|l|}{ miR-Let-7e } \\
\hline \multicolumn{5}{|l|}{ miR-Let-7f } \\
\hline \multicolumn{5}{|l|}{ miR-Let-7g } \\
\hline miR-200 a & & Foxa2 & & Enhanced proliferation and carcinogenesis \\
\hline miR-200 b & Downregulation & BMl1 & Upregulation & \\
\hline miR-145 & & ROCK 1 & & Increased tumorigenesis and invasion \\
\hline miR-34a & & HDAC1 & & Inhibition of invasion and migration \\
\hline miR-141 & & TIAM1 & & Inhibition of proliferation, invasion, and migration \\
\hline miR-7 & & CDR1 & & Suppression \\
\hline $\operatorname{miR}-424$ & & C-myb & & Inhibition of invasion and proliferation \\
\hline miR-9 & & PPAR alpha & & Increase growth and metastasis \\
\hline $\operatorname{miR}-16$ & & $\mathrm{Bcl}-2$ & & Inhibition of proliferation, invasion, and metastasis \\
\hline $\operatorname{miR}-17$ & & TSP 1 & & Increased tumorigenesis \\
\hline $\operatorname{miR}-18$ & & SMAD2 & & Inhibition of migration \\
\hline miR-20a & & $\mathrm{MCl}-1$ & & Increased proliferation and recurrence \\
\hline $\operatorname{miR}-21$ & & KLFS & & Increased progression and metastasis \\
\hline miR-24 & & P53 & & Increased Metastasis and invasion \\
\hline $\operatorname{miR}-27 a$ & & PPAR-y & & Increased proliferation \\
\hline $\operatorname{miR}-495$ & & IGFIR & & Inhibition of proliferation and invasion \\
\hline $\operatorname{miR}-191$ & Upregulation & TIMP3 & Downregulation & Increased proliferation and tumorigenesis \\
\hline miR-155 & & Oncogenesis and casein kinase $1-\alpha(\mathrm{CK} 1-\alpha)$ & & $\begin{array}{l}\text { Increased proliferation and tumorigenesis and } \\
\text { decreased apoptosis }\end{array}$ \\
\hline miR-221 & & $\begin{array}{l}\text { NFkB and downstream genes such as } \\
\text { (bcl-2/MMP-9 and VEGF) }\end{array}$ & & Increased proliferation and tumorigenesis \\
\hline miR-22 & & 3UTR of CD147 & & - \\
\hline $\operatorname{miR}-210$ & & SMAD4-STAT6 & & Increased angiogenesis \\
\hline miR-1246 & Downregulated & CADM1 & Upregulated & Increased migration \\
\hline $\operatorname{miR}-29 c$ & Downregulated & SIRT 1 & Upregulated & Suppression \\
\hline miR-214 & Downregulated & CTNNB 1 & Upregulated & Suppression \\
\hline $\operatorname{miR}-215$ & Downregulated & & Upregulated & Suppression \\
\hline $\operatorname{miR}-142$ & Downregulated & THBS4-TGF- $\beta$ & Upregulated & Increased migration, invasion, and metastasis \\
\hline $\operatorname{miR}-150$ & Downregulated & GAB1 & Upregulated & Suppression \\
\hline miR-93 & Upregulated & PDCD 4 & Downregulated & Increased migration and invasion \\
\hline $\operatorname{miR}-183$ & Upregulated & ETS2 and EGR1 & Downregulated & Carcinogenesis \\
\hline miR-185 & Downregulated & DNTM1 & Upregulated & Increased proliferation \\
\hline miR-194 & Downregulated & MAP4K4 & Upregulated & Increased proliferation \\
\hline miR-101 & Downregulated & 3'UTR of WT-PTEN & Upregulated & Promotion of apoptosis and suppression \\
\hline
\end{tabular}

cell therapies for HCC. In this review, we highlighted the dysregulated expression of relevant miRNAs in HCC and CSCs. Based on the classification of miRNAs as mutually upregulated, mutually downregulated, or mutually dysregulated, we proposed their roles in cancer progression. Despite the lack of data on miRNA expression in MSCs, four miRNAs have dysregulated expression in HCC, CSCs, and MSCs. Based on their functions in MSCs, these miRNAs have been shown to mainly affect differentiation. It is clear, however, that more research is required on the expression profiles of miRNAs in MSCs under physiological conditions and from different tissue sources. Such studies are essential for determining how MSCs regulate and interact with cancer cells and CSCs in HCC.

In the context of clinical applications, miRNAs could represent an opportunity to develop safe strategies for achieving early diagnosis, monitoring disease status, and improving the effectiveness of non-invasive HCC treatment (Valeri et al., 2009). Several studies have shown the effect of miRNAs on enhancing 
TABLE 4 | miRNAs regulated by methylation in HCC.

\begin{tabular}{|c|c|c|c|c|}
\hline miRNA & Function/target & Impact of methylation & Status & $\begin{array}{l}\text { Expression upon } \\
\text { methylation }\end{array}$ \\
\hline miR-148a & Acts as a tumor suppressor (Pan et al., 2014) & Enhanced tumorigenesis and HCC progression & Hypermethylation (He et al., 2015) & Downregulation \\
\hline miR-375 & $\begin{array}{l}\text { Acts as a tumor suppressor by inhibiting } \\
\text { metastasis (Xie D. et al., 2017) } 34\end{array}$ & Increased metastasis and HCC progression & Hypermethylation (He et al., 2015) & Downregulation \\
\hline miR-195 & $\begin{array}{l}\text { It acts as a tumor suppressor through } \\
\text { metastasis inhibition (Wang M. et al., 2015) }\end{array}$ & Enhanced tumorigenesis and HCC progression & Hypermethylation (He et al., 2015) & Downregulation \\
\hline miR-497 & $\begin{array}{l}\text { It acts as a tumor suppressor by inhibiting } \\
\text { metastasis angiogenesis (Yan et al., 2015) }\end{array}$ & Enhanced angiogenesis and metastasis & Hypermethylation (He et al., 2015) & Downregulation \\
\hline miR-378 & Acts as a tumor suppressor (Li et al., 2013) & Enhanced proliferation & Hypermethylation (He et al., 2015) & Downregulation \\
\hline miR-106b & Targets DAB2 (Sun et al., 2018) & Proliferation and migration & Hypomethylation (He et al., 2015) & Upregulation \\
\hline miR-25 & Inhibits RhoGDI1 (Wang C. et al., 2015) & Promotion of both migration and invasion & Hypomethylation (He et al., 2015) & Upregulation \\
\hline miR-93 & Targets PDCD4 (Ji et al., 2017) & Enhanced metastasis and invasion & Hypomethylation (He et al., 2015) & Upregulation \\
\hline miR-23a & Acts as an oncomiR (Bao et al., 2014) & Onset of HCC & Hypomethylation (He et al., 2015) & Upregulation \\
\hline miR-27a & $\begin{array}{l}\text { Targets the peroxisome proliferator-activated } \\
\text { receptor } \gamma \text { gene (Li S. et al., 2015) }\end{array}$ & Increased proliferation capacity & Hypomethylation (He et al., 2015) & Upregulation \\
\hline miR-10a & $\begin{array}{l}\text { Is reported to have several functions. It can } \\
\text { promote migration and invasion, while inhibiting } \\
\text { angiogenesis capacity in HCC and reduce } \\
\text { metastasis capability by targeting Â1-integrin } \\
\text { and MMP-2 (Tang, 2013) }\end{array}$ & $\begin{array}{l}\text { After hypermethylation, metastasis and } \\
\text { angiogenesis are expected to be reduced. On } \\
\text { the other hand, invasion, and migration } \\
\text { capabilities would be reduced }\end{array}$ & $\begin{array}{l}\text { Hypermethylation (Shen et al., } \\
\text { 2012) }\end{array}$ & Downregulation \\
\hline miR-10b & $\begin{array}{l}\text { Acts by targeting CSMD1, RhoC, uPAR, and } \\
\text { MMPs (Liao et al., 2014; Zhu et al., 2016) }\end{array}$ & $\begin{array}{l}\text { Hypermethylation of this miRNA is expected to } \\
\text { reduce levels of migration, proliferation, and } \\
\text { invasion potential }\end{array}$ & $\begin{array}{l}\text { Hypermethylation (Shen et al., } \\
\text { 2012) }\end{array}$ & Downregulation \\
\hline miR-196b & Targets FOXP2 (Yu et al., 2018) & $\begin{array}{l}\text { Decreased metastasis, proliferation, and } \\
\text { migration potential }\end{array}$ & $\begin{array}{l}\text { Hypermethylation (Shen et al., } \\
\text { 2012) }\end{array}$ & Downregulation \\
\hline miR-1 & It acts as an oncomiR (Hu et al., 2015) & Decreased proliferation and migration potential & $\begin{array}{l}\text { Hypermethylation (Datta et al., } \\
\text { 2008) }\end{array}$ & Silenced \\
\hline miR-124 & $\begin{array}{l}\text { Acts as a tumor suppressor by targeting } \\
\text { Baculoviral IAP repeat containing } 3 \text { (BIRC3) } \\
\text { gene (Cao et al., 2018) }\end{array}$ & $\begin{array}{l}\text { Promotion of proliferation and migration } \\
\text { potential }\end{array}$ & $\begin{array}{l}\text { Hypermethylation (Furuta et al., } \\
\text { 2010) }\end{array}$ & Silenced \\
\hline miR-125b & $\begin{array}{l}\text { Acts as a tumor suppressor by targeting (TAZ) } \\
\text { transcriptional co-activator (Li J. et al., 2015) }\end{array}$ & Increased migration and invasion & $\begin{array}{l}\text { Hypermethylation (Alpini et al., } \\
\text { 2011) }\end{array}$ & Silenced \\
\hline miR-203 & $\begin{array}{l}\text { Acts as a tumor suppressor by targeting } \\
\text { survivin (Wei W. et al., 2013) }\end{array}$ & Increased proliferation potential & $\begin{array}{l}\text { Hypermethylation (Furuta et al., } \\
\text { 2010) }\end{array}$ & Silenced \\
\hline $\operatorname{miR}-1247$ & $\begin{array}{l}\text { Acts as a tumor suppressor with Wnt3 being its } \\
\text { target (Chu et al., 2017) }\end{array}$ & Increased proliferation and invasion potential & $\begin{array}{l}\text { Hypermethylation (Anwar et al., } \\
\text { 2013) }\end{array}$ & Downregulation \\
\hline miR-132 & $\begin{array}{l}\text { Acts as a tumor suppressor by targeting } \\
\text { PIK3R3 (Hu et al., 2015) }\end{array}$ & $\begin{array}{l}\text { Increased proliferation, invasion, and migration } \\
\text { potential }\end{array}$ & $\begin{array}{l}\text { Hypermethylation (Wei X. et al., } \\
\text { 2013) }\end{array}$ & Downregulation \\
\hline miR-320 & $\begin{array}{l}\text { Acts as a tumor suppressor where c-Myc is its } \\
\text { target (Xie F. et al., 2017) }\end{array}$ & Increased proliferation and invasion & $\begin{array}{l}\text { Hypermethylation (Shen et al., } \\
\text { 2012) }\end{array}$ & Downregulation \\
\hline miR-596 & No data available & No data available & $\begin{array}{l}\text { Hypermethylation (Anwar et al., } \\
\text { 2013) }\end{array}$ & Downregulation \\
\hline miR-663 & $\begin{array}{l}\text { Inhibits proliferation by targeting the HMGA2 } \\
\text { gene (Huang et al., 2016) }\end{array}$ & Increased proliferation and invasion & $\begin{array}{l}\text { Hypermethylation (Potapova et al., } \\
\text { 2011) }\end{array}$ & Downregulation \\
\hline miR-9 & $\begin{array}{l}\text { Different data are reported: It may act as a } \\
\text { tumor suppressor role by targeting TAZ } \\
\text { (WWTR1) (Higashi et al., 2015). Moreover, it } \\
\text { targets KLF17 and increases the migration and } \\
\text { invasion properties (Sun et al., 2013) }\end{array}$ & $\begin{array}{l}\text { Data reported that hypermethylation could lead } \\
\text { to HCC progression (Higashi et al., 2015), while } \\
\text { other reports suggested that hypermethylation } \\
\text { can lead to reduced migration and invasion } \\
\text { properties (Sun et al., 2013) }\end{array}$ & $\begin{array}{l}\text { Hypermethylation (Anwar et al., } \\
\text { 2013) }\end{array}$ & Downregulation \\
\hline
\end{tabular}

the sensitivity of liver CSCs to treatment. Many dysregulated miRNAs in liver CSCs exert their roles by binding to specific target genes that are key molecules in many pathways. Targeting these miRNAs, their targeted genes, or respective pathways may thus effectively target CSCs, and disturb their role in metastasis, recurrence, and resistance to therapy (Lou et al., 2018). Together with conventional treatment, targeting specific miRNAs involved in tumor progression in combination therapy represent an attractive approach to multifactorial effective therapy to liver cancer (Tao et al., 2018). Although no miRNAs-based drugs are available in current clinical practice (Lou et al., 2018), the antitumor efficiency of modern anticancer drugs like sorafenib 
on HCC was significantly increased in vivo upon delivery of miR-122-exosome to the tumor (Blechacz and Gores, 2008; Lou et al., 2015). Such enhancement is promising to patients of unresectable HCC whose treatment with sorafenib was of limited efficacy, by prolonging survival for only 3 months (Blechacz and Gores, 2008; Kane et al., 2009). Investigating the expression signature of those candidate miRNAs in HCC diagnosis, prognosis, metastasis, and recurrence and determining how these miRNAs genetically and epigenetically regulate the transformation of somatic stem cells to a more chemoresistant phenotype is needed for translation to clinical practice (Valeri et al., 2009; El-Badawy et al., 2017).

\section{REFERENCES}

Ali Hosseini Rad, S. M., Bavarsad, M. S., Arefian, E., Jaseb, K., Shahjahani, M., and Saki, N. (2013). The role of microRNAs in stemness of cancer stem cells. Oncol. Rev. 7, e8. doi: 10.4081/oncol.2013.e8

Alpini, G., Glaser, S. S., Zhang, J. P., Francis, H., Han, Y., Gong, J., et al. (2011). Regulation of placenta growth factor by microRNA-125b in hepatocellular cancer. J. Hepatol. 55, 1339-1345. doi: 10.1016/j.jhep.2011.04.015

Ambros, V. (2004). The functions of animal microRNAs. Nature 431:350. doi: $10.1038 /$ nature02871

Amr, K. S., Ezzat, W. M., Elhosary, Y. A., Hegazy, A. E., Fahim, H. H., and Kamel, R. R. (2016). The potential role of miRNAs 21 and 199-a in early diagnosis of hepatocellular carcinoma. Gene 575, 66-70. doi: 10.1016/j.gene.2015.08.038

Anwar, S. L., Albat, C., Krech, T., Hasemeier, B., Schipper, E., Schweitzer, N., et al. (2013). Concordant hypermethylation of intergenic microRNA genes in human hepatocellular carcinoma as new diagnostic and prognostic marker. Int. J. Cancer. 133, 660-670. doi: 10.1002/ijc.28068

Ashmawy, A. M., Elgeshy, K. M., Abdel Salam, E. T., Ghareeb, M., Kobaisi, M. H., Amin, H. A. A., et al. (2017). Crosstalk between liver-related microRNAs and $\mathrm{Wnt} / \beta$-catenin pathway in hepatocellular carcinoma patients. Arab J. Gastroenterol. 18, 144-150. doi: 10.1016/j.ajg.2017.09.001

Assal, R. A., El Tayebi, H. M., Hosny, K. A., Esmat, G., and Abdelaziz, A. I. (2015). A pleiotropic effect of the single clustered hepatic metastamiRs miR-96-5p and miR-182-5p on insulin-like growth factor II, insulin-like growth factor-1 receptor and insulin-like growth factor-binding protein-3 in hepatocellular carcinoma. Mol. Med. Rep. 12, 645-650. doi: 10.3892/mmr.20 15.3382

Bao, B., Ali, S., Ahmad, A., Azmi, A. S., Li, Y., Banerjee, S., et al. (2012). Hypoxia-induced aggressiveness of pancreatic cancer cells is due to increased expression of VEGF, IL-6, and miR-21, which can be attenuated by CDF treatment. PLoS ONE 7:e50165. doi: 10.1371/journal.pone.00 50165

Bao, L., Zhao, J., Dai, X., Wang, Y., Ma, R., Su, Y., et al. (2014). Correlation between miR-23a and onset of hepatocellular carcinoma. Clin. Res. Hepatol. Gastroenterol. 38, 318-330. doi: 10.1016/j.clinre.2013.12.002

Bartel, D. P. (2004). MicroRNAs: genomics, biogenesis, mechanism, and function. Cell 116, 281-297. doi: 10.1016/S0092-8674(04)00045-5

Baskerville, S., and Bartel, D. P. (2005). Microarray profiling of microRNAs reveals frequent coexpression with neighboring miRNAs and host genes. RNA 11, 241-247. doi: 10.1261/rna.7240905

Beck, B., and Blanpain, C. (2013). Unravelling cancer stem cell potential. Nat. Rev. Cancer 13, 727-738. doi: 10.1038/nrc3597

Bedard, P. L., Hansen, A. R., Ratain, M. J., and Siu, L. L. (2013). Tumour heterogeneity in the clinic. Nature 501, 355-364. doi: 10.1038/nature12627

Bessède, E., Staedel, C., Acuña Amador, L. A., Nguyen, P. H., Chambonnier, L., Hatakeyama, M., et al. (2014). Helicobacter pylori generates cells with cancer stem cell properties via epithelial-mesenchymal transition-like changes. Oncogene 33, 4123-4131. doi: 10.1038/onc.2013.380

Blechacz, B., and Gores, G. J. (2008). Cholangiocarcinoma: advances in pathogenesis, diagnosis, and treatment. Hepatology 48, 308-321. doi: 10.1002/hep. 22310

\section{AUTHOR CONTRIBUTIONS}

Each author has substantially contributed to conducting this study and drafting this manuscript. $\mathrm{MN}$ and $\mathrm{RS}$ wrote the manuscript. MN, ME, and SE analyzed data and moderate figures and tables. While, NE-B contributed in writing and editing of the manuscript.

\section{FUNDING}

This study was funded by the Egyptian Science and Technology Development Fund (STDF Grant ID: 5300).

Borel, F., Konstantinova, P., and Jansen, P. L. (2012). Diagnostic and therapeutic potential of miRNA signatures in patients with hepatocellular carcinoma. $J$. Hepatol. 56, 1371-1383. doi: 10.1016/j.jhep.2011.11.026

Brennecke, J., Hipfner, D. R., Stark, A., Russell, R. B., and Cohen, S. M. (2003) Bantam encodes a developmentally regulated microRNA that controls cell proliferation and regulates the proapoptotic gene hid in Drosophila. Cell 113, 25-36. doi: 10.1016/S0092-8674(03)00231-9

Bu, Y., and Cao, D. (2012). The origin of cancer stem cells. Front. Biosci. 4, 819-830.

Budhu, A., Jia, H. L., Forgues, M., Liu, C. G., Goldstein, D., Lam, A., et al. (2008). Identification of metastasis-related microRNAs in hepatocellular carcinoma. Hepatology 47, 897-907. doi: 10.1002/hep.22160

Bushati, N., and Cohen, S. M. (2007). microRNA functions. Annu. Rev. Cell Dev. Biol. 23, 175-205. doi: 10.1146/annurev.cellbio.23.090506.123406

Cabrera, R., and Nelson, D. R. (2010). Review article: the management of hepatocellular carcinoma. Aliment. Pharmacol. Ther. 31, 461-476. doi: 10.1111/j.1365-2036.2009.04200.x

Calin, G. A., and Croce, C. M. (2006). MicroRNA signatures in human cancers. Nat. Rev. Cancer 6, 857-866. doi: 10.1038/nrc1997

Callegari, E., Elamin, B. K., Sabbioni, S., Gramantieri, L., and Negrini, M. (2013). Role of microRNAs in hepatocellular carcinoma: a clinical perspective. Onco. Targets. Ther. 6, 1167-1178. doi: 10.2147/OTT.S36161

Cao, J., Qiu, J., Wang, X., Lu, Z., Wang, D., Feng, H., et al. (2018). Identification of microRNA-124 in regulation of Hepatocellular carcinoma through BIRC3 and the NF-кB pathway. J. Cancer. 9, 3006-3015. doi: 10.7150/jca.25956

Caruso, S., Bazan, V., Rolfo, C., Insalaco, L., Fanale, D., Bronte, G., et al. (2012). MicroRNAs in colorectal cancer stem cells: new regulators of cancer stemness? Oncogenesis 1:e32. doi: 10.1038/oncsis.2012.33

Chang, R. M., Yang, H., Fang, F., Xu, J. F., and Yang, L. Y. (2014). MicroRNA331-3p promotes proliferation and metastasis of hepatocellular carcinoma by targeting $\mathrm{PH}$ domain and leucine-rich repeat protein phosphatase. Hepatology 60, 1251-1263. doi: 10.1002/hep.27221

Chang, Y., Yan, W., He, X., Zhang, L., Li, C., Huang, H., et al. (2012). miR-375 inhibits autophagy and reduces viability of hepatocellular carcinoma cells under hypoxic conditions. Gastroenterology 143, 177-87 e8. doi: 10.1053/j.gastro.2012.04.009

Chapnik, E., Rivkin, N., Mildner, A., Beck, G., Pasvolsky, R., Metzl-Raz, E., et al. (2014). miR-142 orchestrates a network of actin cytoskeleton regulators during megakaryopoiesis. Elife 3:e01964. doi: 10.7554/eLife.01964

Chen, K., Huang, Y. H., and Chen, J. L. (2013). Understanding and targeting cancer stem cells: therapeutic implications and challenges. Acta Pharmacol. Sin. 34:732-740. doi: 10.1038/aps.2013.27

Chen, L., Chu, F., Cao, Y., Shao, J., and Wang, F. (2015). Serum miR-182 and miR331-3p as diagnostic and prognostic markers in patients with hepatocellular carcinoma. Tumor Biol. 36, 7439-7447. doi: 10.1007/s13277-0153430-2

Chen, S. Y., Ma, D. N., Chen, Q. D., Zhang, J. J., Tian, Y. R., Wang, Z. C., et al. (2017). MicroRNA-200a inhibits cell growth and metastasis by targeting Foxa2 in hepatocellular carcinoma. J. Cancer 8:617. doi: 10.7150/jca.17394

Cho, H. J., Kim, J. K., Nam, J. S., Wang, H. J., Lee, J. H., Kim, B. W. et al. (2015). High circulating microRNA-122 expression is a poor prognostic marker in patients with hepatitis B virus-related hepatocellular carcinoma 
who undergo radiofrequency ablation. Clin. Biochem. 48, 1073-1078. doi: 10.1016/j.clinbiochem.2015.06.019

Cholankeril, G., Patel, R., Khurana, S., and Satapathy, S. K. (2017). Hepatocellular carcinoma in non-alcoholic steatohepatitis: current knowledge and implications for management. World J. Hepatol. 9:533-543. doi: 10.4254/wjh.v9.i11.533

Chu, Y., Fan, W., Guo, W., Zhang, Y., Wang, L., Guo, L., et al. (2017). miR-1247$5 p$ functions as a tumor suppressor in human hepatocellular carcinoma by targeting Wnt3. Oncol. Rep. 38, 343-351. doi: 10.3892/or.2017.5702

Chuang, J. C., and Jones, P. A. (2007). Epigenetics and microRNAs. Pediatr. Res. 61(5 Pt 2), 24R-29R. doi: 10.1203/pdr.0b013e3180457684

Connolly, E., Melegari, M., Landgraf, P., Tchaikovskaya, T., Tennant, B. C., Slagle, B. L., et al. (2008). Elevated expression of the miR-17-92 polycistron and miR-21 in hepadnavirus-associated hepatocellular carcinoma contributes to the malignant phenotype. Am. J. Pathol. 173, 856-864. doi: 10.2353/ajpath.2008.080096

Cummins, J. M., and Velculescu, V. E. (2006). Implications of micro-RNA profiling for cancer diagnosis. Oncogene 25, 6220-6227. doi: 10.1038/si.onc.1209914

Dambal, S., Shah, M., Mihelich, B., and Nonn, L. (2015). The microRNA-183 cluster: the family that plays together stays together. Nucleic Acids Res. 43, 7173-7188. doi: 10.1093/nar/gkv703

Datta, J., Kutay, H., Nasser, M. W., Nuovo, G. J., Wang, B., Majumder, S., et al. (2008). Methylation mediated silencing of MicroRNA-1 gene and its role in hepatocellular carcinogenesis. Cancer Res. 68, 5049-5058. doi: 10.1158/0008-5472.CAN-07-6655

Dhanasekaran, R., Limaye, A., and Cabrera, R. (2012). Hepatocellular carcinoma: current trends in worldwide epidemiology, risk factors, diagnosis, and therapeutics. Hepat. Med. 4:19-37. doi: 10.2147/HMER.S16316

Dhayat, S. A., Mardin, W. A., Köhler, G., Bahde, R., Vowinkel, T., Wolters, H., et al. (2014). The microRNA-200 family-a potential diagnostic marker in hepatocellular carcinoma? J. Surg. Oncol. 110, 430-438. doi: 10.1002/jso.23668

Duursma, A. M., Kedde, M., Schrier, M., le Sage, C., and Agami, R. (2008). miR-148 targets human DNMT3b protein coding region. RNA 14, 872-877. doi: $10.1261 /$ rna. 972008

Eaves, C. J., and Humphries, R. K. (2010). Acute myeloid leukemia and the WNT pathway. N. Engl. J. Med. 362, 2326-2327. doi: 10.1056/NEJMcibr1003522

El Tayebi, H. M., Hosny, K. A., Esmat, G., Breuhahn, K., and Abdelaziz, A. I. (2012). miR-615-5p is restrictedly expressed in cirrhotic and cancerous liver tissues and its overexpression alleviates the tumorigenic effects in hepatocellular carcinoma. FEBS Lett. 586, 3309-3316. doi: 10.1016/j.febslet.2012.06.054

El Tayebi, H. M., Waly, A. A., Assal, R. A., Hosny, K. A., Esmat, G., and Abdelaziz, A. I. (2015). Transcriptional activation of the IGF-II/IGF-1R axis and inhibition of IGFBP-3 by miR-155 in hepatocellular carcinoma. Oncol. Lett. 10, 3206-3212. doi: 10.3892/ol.2015.3725

El-Abd, N. E., Fawzy, N. A., El-Sheikh, S. M., and Soliman, M. E. (2015). Circulating miRNA-122, miRNA-199a, and miRNA-16 as biomarkers for early detection of hepatocellular carcinoma in Egyptian patients with chronic hepatitis C virus infection. Mol. Diagn. Ther. 19, 213-220. doi: 10.1007/s40291-015-0148-1

El-Badawy, A., Ghoneim, M. A., Gabr, M. M., Salah, R. A., Mohamed, I. K., Amer, M., et al. (2017). Cancer cell-soluble factors reprogram mesenchymal stromal cells to slow cycling, chemoresistant cells with a more stem-like state. Stem Cell Res. Ther. 8, 254. doi: 10.1186/s13287-017-0709-9

El-Halawany, M. S., Ismail, H. M., Zeeneldin, A. A., Elfiky, A., Tantawy, M., Kobaisi, M. H., et al. (2015). Investigating the pretreatment miRNA expression patterns of advanced hepatocellular carcinoma patients in association with response to TACE treatment. Biomed. Res. Int. 2015:649750. doi: $10.1155 / 2015 / 649750$

El-Serag, H. B. (2002). Hepatocellular carcinoma and hepatitis C in the United States. Hepatology. 36(5 Suppl. 1), S74-83. doi: 10.1053/jhep.2002.36807

Eshelman, M. A., and Yochum, G. S. (2016). The Wnt/ $\beta$-catenin pathway is activated by miR-1246 in liver cancer stem cells. Transl. Cancer Res. S1457S1460. doi: $10.21037 /$ tcr.2016.12.57

Espada, J., Calvo, M. B., Díaz-Prado, S., and Medina, V. (2009). Wnt signalling and cancer stem cells. Clin. Transl. Oncol. 11, 411-427. doi: 10.1007/s12094-009-0380-4

Fawzy, I. O., Hamza, M. T., Hosny, K. A., Esmat, G., and Abdelaziz, A. I. (2016). Abrogating the interplay between IGF2BP1, 2 and 3 and IGF1R by let-7i arrests hepatocellular carcinoma growth. Growth Factors. 34, 42-50. doi: 10.3109/08977194.2016.1169532

Fornari, F., Gramantieri, L., Ferracin, M., Veronese, A., Sabbioni, S., Calin, G. A., et al. (2008). MiR-221 controls CDKN1C/p57 and CDKN1B/p27 expression in human hepatocellular carcinoma. Oncogene 27, 5651-5661. doi: 10.1038/onc.2008.178

Fregni, G., Quinodoz, M., Möller, E., Vuille, J., Galland, S., Fusco, C., et al. (2018). Reciprocal modulation of mesenchymal stem cells and tumor cells promotes lung cancer metastasis. EBioMed. 29, 128-145. doi: 10.1016/j.ebiom.2018.02.017

Furuta, M., Kozaki, K., Tanimoto, K., Tanaka, S., Arii, S., Shimamura, T., et al. (2013). The tumor-suppressive miR-497-195 cluster targets multiple cell-cycle regulators in hepatocellular carcinoma. PLoS ONE 8:e60155. doi: 10.1371/journal.pone.0060155

Furuta, M., Kozaki, K. I., Tanaka, S., Arii, S., Imoto, I., Inazawa, J., et al. (2010). miR-124 and miR-203 are epigenetically silenced tumorsuppressive microRNAs in hepatocellular carcinoma. Carcinogenesis 31, 766-776. doi: 10.1093/carcin/bgp250

Gailhouste, L., Gomez-Santos, L., Hagiwara, K., Hatada, I., Kitagawa, N., Kawaharada, K., et al. (2013). miR-148a plays a pivotal role in the liver by promoting the hepatospecific phenotype and suppressing the invasiveness of transformed cells. Hepatology 58, 1153-1165. doi: 10.1002/hep. 26422

Gao, H., Priebe, W., Glod, J., and Banerjee, D. (2009). Activation of signal transducers and activators of transcription 3 and focal adhesion kinase by stromal cell-derived factor 1 is required for migration of human mesenchymal stem cells in response to tumor cell-conditioned medium. Stem Cells 27, 857-865. doi: 10.1002/stem.23

Garg, M. (2015). Emerging role of microRNAs in cancer stem cells: implications in cancer therapy. World J. Stem Cells 7, 1078-1089. doi: 10.4252/wjsc.v7.i8.1078

Garofalo, M., Di Leva, G., Romano, G., Nuovo, G., Suh, S. S., Ngankeu, A., et al. (2009). miR-221\&222 regulate TRAIL resistance and enhance tumorigenicity through PTEN and TIMP3 downregulation. Cancer Cell. 16, 498-509. doi: 10.1016/j.ccr.2009.10.014

George, G. P., and Mittal, R. D. (2010). MicroRNAs: potential biomarkers in cancer. Indian J. Clin. Biochem. 25, 4-14. doi: 10.1007/s12291-010-0008-z

Ghaderi, A., and Abtahi, S. (2018). Mesenchymal stem cells: miraculous healers or dormant killers? Stem Cell Rev. Rep. 14, 722-733. doi: 10.1007/s12015-018-9824-y

Gramantieri, L., Ferracin, M., Fornari, F., Veronese, A., Sabbioni, S., Liu, C. G., et al. (2007). Cyclin G1 is a target of miR-122a, a microRNA frequently downregulated in human hepatocellular carcinoma. Cancer Res. 67, 6092-6099. doi: 10.1158/0008-5472.CAN-06-4607

Gregory, P. A., Bert, A. G., Paterson, E. L., Barry, S. C., Tsykin, A., Farshid, G., et al. (2008). The miR-200 family and miR-205 regulate epithelial to mesenchymal transition by targeting ZEB1 and SIP1. Nat. Cell Biol. 10, 593-601. doi: 10.1038/ncb1722

Griffiths-Jones, S., Grocock, R. J., van Dongen, S., Bateman, A., and Enright, A. J. (2006). miRBase: microRNA sequences, targets and gene nomenclature. Nucleic Acids Res. 34, D140-D144. doi: 10.1093/nar/gki112

Gutschner, T., Hämmerle, M., Pazaitis, N., Bley, N., Fiskin, E., Uckelmann, H., et al. (2014). Insulin-like growth factor 2 mRNA-binding protein 1 (IGF2BP1) is an important protumorigenic factor in hepatocellular carcinoma. Hepatology 59, 1900-1911. doi: 10.1002/hep.26997

Guzman, G., Brunt, E. M., Petrovic, L. M., Chejfec, G., Layden, T. J., Cotler, S. J., et al. (2008). Does nonalcoholic fatty liver disease predispose patients to hepatocellular carcinoma in the absence of cirrhosis? Arch. Pathol. Lab. Med. 132, 1761-1766. doi: 10.1043/1543-2165-132.11.1761

Habashy, D. A., El Tayebi, H. M., Fawzy, I. O., Hosny, K. A., Esmat, G., and Abdelaziz, A. I. (2016). Interplay between microRNA-17-5p, insulin-like growth factor-II through binding protein-3 in hepatocellular carcinoma. World J. Hepatol. 8, 976-984. doi: 10.4254/wjh.v8.i23.976

Han, K., Li, J., Zhao, H., Liang, P., Huang, X., Zheng, L., et al. (2014). Identification of the typical miRNAs and target genes in hepatocellular carcinoma. Mol. Med. Rep. 10, 229-235. doi: 10.3892/mmr.2014.2194

Han, Z. B., Chen, H. Y., Fan, J. W., Wu, J. Y., Peng, Z. H., and Wang, Z. W. (2013). Expression and survival prediction of microRNA-155 in hepatocellular carcinoma after liver transplantation. Zhonghua Yi Xue Za Zhi. 93, 884-887. 
Hassan, M. Q., Gordon, J. A., Beloti, M. M., Croce, C. M., van Wijnen, A. J., Stein, J. L., et al. (2010). A network connecting Runx2, SATB2, and the miR23a $\sim 27 \mathrm{a} \sim 24-2$ cluster regulates the osteoblast differentiation program. Proc. Natl. Acad. Sci. U.S.A. 107, 19879-19884. doi: 10.1073/pnas.1007698107

He, X. X., Chang, Y., Meng, F. Y., Wang, M. Y., Xie, Q. H., Tang, F., et al. (2012). MicroRNA-375 targets AEG-1 in hepatocellular carcinoma and suppresses liver cancer cell growth in vitro and in vivo. Oncogene 31, 3357-3369. doi: 10.1038/onc.2011.500

He, X. X., Kuang, S. Z., Liao, J. Z., Xu, C. R., Chang, Y., Wu, Y. L., et al. (2015). The regulation of microRNA expression by DNA methylation in hepatocellular carcinoma. Mol. Biosyst. 11, 532-539. doi: 10.1039/C4MB00563E

He, Y., Cui, Y., Wang, W., Gu, J., Guo, S., Ma, K., et al. (2011). Hypomethylation of the hsa-miR-191 locus causes high expression of hsa-mir-191 and promotes the epithelial-to-mesenchymal transition in hepatocellular carcinoma. Neoplasia 13, 841-853. doi: 10.1593/neo.11698

Heo, I., Joo, C., Cho, J., Ha, M., Han, J., and Kim, V. N. (2008). Lin28 mediates the terminal uridylation of let-7 precursor MicroRN. Mol. Cell 32, 276-284. doi: 10.1016/j.molcel.2008.09.014

Higashi, T., Hayashi, H., Ishimoto, T., Takeyama, H., Kaida, T., Arima, K., et al. (2015). miR-9-3p plays a tumour-suppressor role by targeting TAZ (WWTR1) in hepatocellular carcinoma cells. Br. J. Cancer 113, 252-258. doi: 10.1038/bjc.2015.170

Hill, B. S., Pelagalli, A., Passaro, N., and Zannetti, A. (2017). Tumor-educated mesenchymal stem cells promote pro-metastatic phenotype. Oncotarget 8, 73296-73311. doi: 10.18632/oncotarget.20265

Hu, C., Shen, S. Q., Cui, Z. H., Chen, Z. B., and Li, W. (2015). Effect of microRNA1 on hepatocellular carcinoma tumor endothelial cells. World J. Gastroenterol. 21, 5884-5892. doi: 10.3748/wjg.v21.i19.5884

Huang, S., He, X., Ding, J., Liang, L., Zhao, Y., Zhang, Z., et al. (2008). Upregulation of miR-23a approximately 27 a approximately 24 decreases transforming growth factor-beta-induced tumor-suppressive activities in human hepatocellular carcinoma cells. Int. J. Cancer 123, 972-978. doi: 10.1002/ijc. 23580

Huang, W., Li, J., Guo, X., Zhao, Y., and Yuan, X. (2016). miR-663a inhibits hepatocellular carcinoma cell proliferation and invasion by targeting HMGA2. Biomed. Pharmacother. 81, 431-438. doi: 10.1016/j.biopha.2016.04.034

Huang, X. B., Li, J., Zheng, L., Zuo, G. H., Han, K. Q., Li, H. Y., et al. (2013). Bioinformatics analysis reveals potential candidate drugs for HCC. Pathol. Oncol. Res. 19, 251-258. doi: 10.1007/s12253-012-9576-y

Huang, X. H., Wang, Q., Chen, J. S., Fu, X. H., Chen, X. L., Chen, L. Z., et al. (2009). Bead-based microarray analysis of microRNA expression in hepatocellular carcinoma: miR-338 is downregulated. Hepatol. Res. 39, 786-794. doi: 10.1111/j.1872-034X.2009.00502.x

Hung, C. H., Hu, T. H., Lu, S. N., Kuo, F. Y., Chen, C. H., Wang, J. H., et al. (2016). Circulating micro RNAs as biomarkers for diagnosis of early hepatocellular carcinoma associated with hepatitis B virus. Int. J. Cancer 138, 714-720. doi: 10.1002/ijc. 29802

Hwang-Verslues, W. W., Chang, P. H., Wei, P. C., Yang, C. Y., Huang, C. K., Kuo, W. H., et al. (2011). miR-495 is upregulated by E12/E47 in breast cancer stem cells, and promotes oncogenesis and hypoxia resistance via downregulation of E-cadherin and REDD1. Oncogene 30, 2463-2474. doi: 10.1038/onc.2010.618

Iorio, M. V., and Croce, C. M. (2009). MicroRNAs in cancer: small molecules with a huge impact. J. Clin. Oncol. 27, 5848-5856. doi: 10.1200/JCO.2009.24.0317

Ip, B., and Wang, X.-D. (2014). Non-alcoholic steatohepatitis and hepatocellular carcinoma: implications for lycopene intervention. Nutrients 6, 124-162. doi: 10.3390/nu6010124

Itoh, T., Nozawa, Y., and Akao, Y. (2009). MicroRNA-141 and-200a are involved in bone morphogenetic protein-2-induced mouse pre-osteoblast differentiation by targeting distal-less homeobox 5. J. Biol. Chem. 284, 19272-19279. doi: 10.1074/jbc.M109.014001

Ji, C., Liu, H., Yin, Q., Li, H., and Gao, H. (2017). miR-93 enhances hepatocellular carcinoma invasion and metastasis by EMT via targeting PDCD4. Biotechnol. Lett. 39, 1621-1629. doi: 10.1007/s10529-017-2403-5

Ji, J., Shi, J., Budhu, A., Yu, Z., Forgues, M., Roessler, S., et al. (2009a). MicroRNA expression, survival, and response to interferon in liver cancer. N. Engl. J. Med. 361, 1437-1447. doi: 10.1056/NEJMoa0901282

Ji, J., Yamashita, T., Budhu, A., Forgues, M., Jia, H. L., Li, C., et al. (2009b). Identification of microRNA-181 by genome-wide screening as a critical player in EpCAM-positive hepatic cancer stem cells. Hepatology 50, 472-480. doi: 10.1002/hep.22989

Jiang, J., Gusev, Y., Aderca, I., Mettler, T. A., Nagorney, D. M., Brackett, D. J., et al. (2008). Association of MicroRNA expression in hepatocellular carcinomas with hepatitis infection, cirrhosis, and patient survival. Clin. Cancer Res. 14, 419-427. doi: 10.1158/1078-0432.CCR-07-0523

Jiang, L., Cheng, Q., Zhang, B. H., and Zhang, M. Z. (2015). Circulating microRNAs as biomarkers in hepatocellular carcinoma screening: a validation set from China. Medicine. 94:e13434. doi: 10.1097/MD.0000000000000603

Johnson, S. M., Grosshans, H., Shingara, J., Byrom, M., Jarvis, R., Cheng, A., et al. (2005). RAS is regulated by the let-7 microRNA family. Cell 120, 635-647. doi: 10.1016/j.cell.2005.01.014

Kane, R. C., Farrell, A. T., Madabushi, R., Booth, B., Chattopadhyay, S., Sridhara, R., et al. (2009). Sorafenib for the treatment of unresectable hepatocellular carcinoma. Oncologist 14, 95-100. doi: 10.1634/theoncologist.2008-0185

Kawai, T., Yasuchika, K., Ishii, T., Katayama, H., Yoshitoshi, E. Y., Ogiso, S., et al. (2015). Keratin 19, a cancer stem cell marker in human hepatocellular carcinoma. Clin. Cancer Res. 21, 3081-3091. doi: 10.1158/1078-0432.CCR-14-1936

Kim, Y. J., Hwang, S. H., Cho, H. H., Shin, K. K., Bae, Y. C., Jung, J. S. et al. (2012). MicroRNA 21 regulates the proliferation of human adipose tissue-derived mesenchymal stem cells and high-fat diet-induced obesity alters microRNA 21 expression in white adipose tissues. J. Cell. Physiol. 227, 183-193. doi: $10.1002 /$ jcp. 22716

Klein, C. A. (2013). Selection and adaptation during metastatic cancer progression. Nature 501, 365-372. doi: 10.1038/nature12628

Klymenko, Y., and Nephew, K. (2018). Epigenetic crosstalk between the tumor microenvironment and ovarian cancer cells: a therapeutic road less traveled. Cancers 10:E295. doi: 10.3390/cancers10090295

Köberle, V., Kronenberger, B., Pleli, T., Trojan, J., Imelmann, E., PevelingOberhag, J., et al. (2013). Serum microRNA-1 and microRNA-122 are prognostic markers in patients with hepatocellular carcinoma. Eur. J. Cancer. 49, 3442-3449. doi: 10.1016/j.ejca.2013.06.002

Krol, J., Loedige, I., and Filipowicz, W. (2010). The widespread regulation of microRNA biogenesis, function and decay. Nat. Rev. Genet. 11, 597-610. doi: $10.1038 / \mathrm{nrg} 2843$

Lashine, Y. A., Seoudi, A. M., Salah, S., and Abdelaziz, A. I. (2011). Expression signature of microRNA-181-a reveals its crucial role in the pathogenesis of paediatric systemic lupus erythematosus. Clin. Exp. Rheumatol. 29, 351-357.

Lau, W. Y., and Lai, E. C. (2008). Hepatocellular carcinoma: current management and recent advances. HBPD INT 7, 237-257.

Law, P. T., Ching, A. K., Chan, A. W., Wong, Q. W., Wong, C. K., To, K. F., et al. (2012). MiR-145 modulates multiple components of the insulin-like growth factor pathway in hepatocellular carcinoma. Carcinogenesis 33, 1134-1141. doi: 10.1093/carcin/bgs130

Leal, J. A., and Lleonart, M. E. (2013). MicroRNAs and cancer stem cells: therapeutic approaches and future perspectives. Cancer Lett. 338, 174-183. doi: 10.1016/j.canlet.2012.04.020

Leung, W. K., He, M., Chan, A. W., Law, P. T., and Wong, N. (2015). Wnt/beta-catenin activates MiR-183/96/182 expression in hepatocellular carcinoma that promotes cell invasion. Cancer Lett. 362, 97-105. doi: 10.1016/j.canlet.2015.03.023

Lewis, B. P., Burge, C. B., and Bartel, D. P. (2005). Conserved seed pairing, often flanked by adenosines, indicates that thousands of human genes are microRNA targets. Cell 120, 15-20. doi: 10.1016/j.cell.2004.12.035

Li, B., Huang, P., Qiu, J., Liao, Y., Hong, J., and Yuan, Y. (2014). MicroRNA$130 \mathrm{a}$ is down-regulated in hepatocellular carcinoma and associates with poor prognosis. Med. Oncol. 31:230. doi: 10.1007/s12032-014-0230-2

Li, B., Lu, Y., Yu, L., Han, X., Wang, H., Mao, J., et al. (2017). miR-221/222 promote cancer stem-like cell properties and tumor growth of breast cancer via targeting PTEN and sustained Akt/NF-кB/COX-2 activation. Chem. Biol. Interact. 277, 33-42. doi: 10.1016/j.cbi.2017.08.014

Li, J., Fang, L., Yu, W., and Wang, Y. (2015). MicroRNA-125b suppresses the migration and invasion of hepatocellular carcinoma cells by targeting transcriptional coactivator with PDZ-binding motif. Oncol. Lett. 9, 1971-1975. doi: 10.3892/ol.2015.2973

Li, J., Fu, H., Xu, C., Tie, Y., Xing, R., Zhu, J., et al. (2010). miR183 inhibits TGF- $\beta 1$-induced apoptosis by downregulation of PDCD4 
expression in human hepatocellular carcinoma cells. BMC Cancer. 10:354. doi: 10.1186/1471-2407-10-354

Li, L., Tang, J., Zhang, B., Yang, W., LiuGao, M., Wang, R., et al. (2015). Epigenetic modification of MiR-429 promotes liver tumour-initiating cell properties by targeting Rb binding protein 4. Gut 64, 156-167. doi: 10.1136/gutjnl-2013-305715

Li, L. H., Gao, Q., Wang, X. Y., and Guo, Z. J. (2013). [miR-378 suppresses HBV-related hepatocellular carcinoma tumor growth by directly targeting the insulin-like growth factor 1 receptor]. Zhonghua Gan Zang Bing Za Zhi. 21, 609-613. doi: 10.3760/cma.j.issn.1007-3418.2013.08.011

Li, N., Fu, H., Tie, Y., Hu, Z., Kong, W., Wu, Y., et al. (2009). miR-34a inhibits migration and invasion by down-regulation of c-Met expression in human hepatocellular carcinoma cells. Cancer Lett. 275, 44-53. doi: 10.1016/j.canlet.2008.09.035

Li, S., Li, J., Fei, B. Y., Shao, D., Pan, Y., Mo, Z. H., et al. (2015). MiR-27a promotes hepatocellular carcinoma cell proliferation through suppression of its target gene peroxisome proliferator-activated receptor $\gamma$. Chinese Med. J. 128, 941-947. doi: 10.4103/0366-6999.154302

Li, T., Yin, J., Yuan, L., Wang, S., Yang, L., Du, X., et al. (2014). Downregulation of microRNA-139 is associated with hepatocellular carcinoma risk and short-term survival. Oncol. Rep. 31, 1699-1706. doi: 10.3892/or.2014.3032

Li, Y., Tan, W., Neo, T. W., Aung, M. O., Wasser, S., Lim, S. G., et al. (2009). Role of the miR-106b-25 microRNA cluster in hepatocellular carcinoma. Cancer Sci. 100, 1234-1242. doi: 10.1111/j.1349-7006.2009.01164.x

Liao, C. G., Kong, L. M., Zhou, P., Yang, X. L., Huang, J. G., Zhang, H. L., et al. (2014). miR-10b is overexpressed in hepatocellular carcinoma and promotes cell proliferation, migration and invasion through RhoC, uPAR and MMPs. J. Transl. Med. 12, 234-234. doi: 10.1186/s12967-014-0234-x

Lin, S. L., Miller, J. D., and Ying, S. Y. (2006). Intronic microRNA (miRNA). J. Biomed. Biotechnol. 2006:26818. doi: 10.1155/JBB/2006/26818

Liu, B., Li, J., and Cairns, M. J. (2014). Identifying miRNAs, targets and functions. Brief. Bioinformatics 15, 1-19. doi: 10.1093/bib/bbs075

Liu, D., Wu, J., Liu, M., Yin, H., He, J., and Zhang, B. (2015). Downregulation of miRNA-30c and miR-203a is associated with hepatitis C virus core protein-induced epithelial-mesenchymal transition in normal hepatocytes and hepatocellular carcinoma cells. Biochem. Biophys. Res. Commun. 464, 1215-1221. doi: 10.1016/j.bbrc.2015.07.107

Liu, D. Z., Zhang, H. Y., Long, X. L., Zou, S. L., Zhang, X. Y., Han, G. Y., et al. (2015). MIR-150 promotes prostate cancer stem cell development via suppressing p27Kip1. Eur. Rev. Med. Pharmacol. Sci. 19, 4344-4352.

Liu, F., Kong, X., Lv, L., and Gao, J. (2015). TGF-betal acts through miR-155 to down-regulate TP53INP1 in promoting epithelial-mesenchymal transition and cancer stem cell phenotypes. Cancer Lett. 359, 288-298. doi: 10.1016/j.canlet.2015.01.030

Liu, J., Stevens, P. D., and Gao, T. (2011). mTOR-dependent regulation of PHLPP expression controls the rapamycin sensitivity in cancer cells. J. Biol. Chem. 286, 6510-6520. doi: 10.1074/jbc.M110.183087

Liu, J. L., Jiang, L., Lin, Q. X., Deng, C. Y., Mai, L. P., Zhu, J. N., et al. (2012). MicroRNA 16 enhances differentiation of human bone marrow mesenchymal stem cells in a cardiac niche toward myogenic phenotypes in vitro. Life Sci. 90, 1020-1026. doi: 10.1016/j.lfs.2012.05.011

Liu, L., Cai, X., Liu, E., Tian, X., and Tian, C. (2017). MicroRNA-18a promotes proliferation and metastasis in hepatocellular carcinoma via targeting KLF4. Oncotarget 8, 68263-68269. doi: 10.18632/oncotarget.19293

Liu, Y., Liu, W., Hu, C., Xue, Z., Wang, G., Ding, B., et al. (2011). MiR-17 modulates osteogenic differentiation through a coherent feed-forward loop in mesenchymal stem cells isolated from periodontal ligaments of patients with periodontitis. Stem Cells 29, 1804-1816. doi: 10.1002/stem.728

Lou, G., Song, X., Yang, F., Wu, S., Wang, J., Chen, Z., et al. (2015). Exosomes derived from miR-122-modified adipose tissue-derived MSCs increase chemosensitivity of hepatocellular carcinoma. J. Hematol. Oncol. 8:122. doi: 10.1186/s13045-015-0220-7

Lou, W., Liu, J., Gao, Y., Zhong, G., Ding, B., Xu, L., et al. (2018). MicroRNA regulation of liver cancer stem cells. Am. J. Cancer Res. 8, 1126-1141.

Lu, C. Y., Lin, K. Y., Tien, M. T., Wu, C. T., Uen, Y. H., and Tseng, T. L. (2013). Frequent DNA methylation of MiR-129-2 and its potential clinical implication in hepatocellular carcinoma. Genes Chromosomes Cancer 52, 636-643. doi: 10.1002/gcc.22059
Lu, J., Getz, G., Miska, E. A., Alvarez-Saavedra, E., Lamb, J., Peck, D., et al. (2005). MicroRNA expression profiles classify human cancers. Nature 435, 834-838. doi: $10.1038 /$ nature03702

Luo, J., Chen, M., Huang, H., Yuan, T., Zhang, M., Zhang, K., et al. (2013). Circulating microRNA-122a as a diagnostic marker for hepatocellular carcinoma. Onco. Targets. Ther. 6, 577-583. doi: 10.2147/OTT.S44215

Ma, S., Tang, K. H., Chan, Y. P., Lee, T. K., Kwan, P. S., Castilho, A., et al. (2010). miR-130b Promotes CD133(+) liver tumor-initiating cell growth and self-renewal via tumor protein 53-induced nuclear protein 1. Cell Stem Cell 7, 694-707. doi: 10.1016/j.stem.2010.11.010

Malaguarnera, G., Cataudella, E., Giordano, M., Nunnari, G., Chisari, G., and Malaguarnera, M. (2012). Toxic hepatitis in occupational exposure to solvents. World J. Gastroenterol. 18, 2756-2766. doi: 10.3748/wjg.v18.i22.2756

Marrero, J. A., Fontana, R. J., Su, G. L., Conjeevaram, H. S., Emick, D. M., and Lok, A. S. (2002). NAFLD may be a common underlying liver disease in patients with hepatocellular carcinoma in the United States. Hepatology 36, 1349-1354. doi: 10.1002/hep.1840360609

Martinez-Sanchez, A., Dudek, K. A., and Murphy, C. L. (2012). Regulation of human chondrocyte function through direct inhibition of cartilage master regulator SOX9 by microRNA-145 (miRNA-145). J. Biol. Chem. 287, 916-924. doi: 10.1074/jbc.M111.302430

Meacham, C. E., and Morrison, S. J. (2013). Tumour heterogeneity and cancer cell plasticity. Nature 501, 328-337. doi: 10.1038/nature12624

Mei, Y., Bian, C., Li, J., Du, Z., Zhou, H., Yang, Z., et al. (2013). miR-21 modulates the ERK-MAPK signaling pathway by regulating SPRY2 expression during human mesenchymal stem cell differentiation. J. Cell. Biochem. 114, 1374-1384. doi: $10.1002 / j \mathrm{cb} .24479$

Meng, F.-L., Wang, W., and Jia, D.- W. (2014). Diagnostic and prognostic significance of serum miR-24-3p in HBV-related hepatocellular carcinoma. Med. Oncol. 31:177. doi: 10.1007/s12032-014-0177-3

Mens, M. M. J., and Ghanbari, M. (2018). Cell cycle regulation of stem cells by MicroRNAs. Stem Cell Rev. Rep. 14, 309-322. doi: 10.1007/s12015-01 8-9808-y

Miranda, K. C., Huynh, T., Tay, Y., Ang, Y. S., Tam, W. L., Thomson, A. M., et al. (2006). A pattern-based method for the identification of MicroRNA binding sites and their corresponding heteroduplexes. Cell 126, 1203-1217. doi: 10.1016/j.cell.2006.07.031

Mohammed, M. K., Shao, C., Wang, J., Wei, Q., Wang, X., Collier, Z., et al. (2016). Wnt/beta-catenin signaling plays an ever-expanding role in stem cell self-renewal, tumorigenesis and cancer chemoresistance. Genes Dis. 3, 11-40. doi: 10.1016/j.gendis.2015.12.004

Murakami, Y., Tamori, A., Itami, S., Tanahashi, T., Toyoda, H., Tanaka, M., et al. (2013). The expression level of miR-18b in hepatocellular carcinoma is associated with the grade of malignancy and prognosis. BMC Cancer 13:566. doi: 10.1186/1471-2407-13-99

Murakami, Y., Yasuda, T., Saigo, K., Urashima, T., Toyoda, H., Okanoue, T., et al. (2006). Comprehensive analysis of microRNA expression patterns in hepatocellular carcinoma and non-tumorous tissues. Oncogene 25, 2537-2545. doi: 10.1038/sj.onc. 1209283

Negrini, M., Gramantieri, L., Sabbioni, S., and Croce, C. M. (2011). microRNA involvement in hepatocellular carcinoma. Anticancer Agents Med. Chem. 11, 500-521. doi: 10.2174/187152011796011037

Negrini, M., Nicoloso, M. S., and Calin, G. A. (2009). MicroRNAs and cancernew paradigms in molecular oncology. Curr. Opin. Cell Biol. 21, 470-479. doi: 10.1016/j.ceb.2009.03.002

Nie, Y., Han, B. M., Liu, X. B., Yang, J. J., Wang, F., Cong, X. F., et al. (2011). Identification of MicroRNAs involved in hypoxia- and serum deprivation-induced apoptosis in mesenchymal stem cells. Int. J. Biol. Sci. 7, 762-768. doi: 10.7150/ijbs.7.762

O’Brien, C. A., Pollett, A., Gallinger, S., and Dick, J. E. (2007). A human colon cancer cell capable of initiating tumour growth in immunodeficient mice. Nature 445, 106-110. doi: 10.1038/nature05372

Pan, L., Huang, S., He, R., Rong, M., Dang, Y., Chen, G., et al. (2014). Decreased expression and clinical significance of miR-148a in hepatocellular carcinoma tissues. Eur. J. Med. Res. 19, 68-68. doi: 10.1186/s40001-0140068-2

Pan, W., Zhu, S., Yuan, M., Cui, H., Wang, L., Luo, X., et al. (2010). MicroRNA21 and microRNA-148a contribute to DNA hypomethylation in lupus CD4+ T 
cells by directly and indirectly targeting DNA methyltransferase 1. J. Immunol. 184, 6773-6781. doi: 10.4049/jimmunol.0904060

Peter, M. E. (2009). Let-7 and miR-200 microRNAs: Guardians against pluripotency and cancer progression. Cell Cycle 8, 843-852. doi: $10.4161 /$ cc.8.6.7907

Peuget, S., Bonacci, T., Soubeyran, P., Iovanna, J., and Dusetti, N. J. (2014). Oxidative stress-induced p53 activity is enhanced by a redoxsensitive TP53INP1 SUMOylation. Cell Death Differ. 21, 1107-1118. doi: $10.1038 /$ cdd. 2014.28

Peveling-Oberhag, J., Seiz, A., Döring, C., Hartmann, S., Köberle, V., Liese, J., et al. (2014). MicroRNA profiling of laser-microdissected hepatocellular carcinoma reveals an oncogenic phenotype of the tumor capsule. Transl. Oncol. 7, 672-680. doi: 10.1016/j.tranon.2014.09.003

Pode-Shakked, N., Shukrun, R., Mark-Danieli, M., Tsvetkov, P., Bahar, S., PriChen, S., et al. (2013). The isolation and characterization of renal cancer initiating cells from human Wilms' tumour xenografts unveils new therapeutic targets. EMBO Mol. Med. 5, 18-37. doi: 10.1002/emmm.201201516

Potapova, A., Albat, C., Hasemeier, B., Haeussler, K., Lamprecht, S., Suerbaum, S., et al. (2011). Systematic cross-validation of 454 sequencing and pyrosequencing for the exact quantification of DNA methylation patterns with single CpG resolution. BMC Biotechnol. 11:6. doi: 10.1186/1472-6750-11-6

Pritchard, C. C., Cheng, H. H., and Tewari, M. (2012). MicroRNA profiling: approaches and considerations. Nat. Rev. Genet. 13, 358-369. doi: $10.1038 / \mathrm{nrg} 3198$

Reddy, S. K., Steel, J. L., Chen, H. W., DeMateo, D. J., Cardinal, J., Behari, J., et al. (2012). Outcomes of curative treatment for hepatocellular cancer in nonalcoholic steatohepatitis versus hepatitis $\mathrm{C}$ and alcoholic liver disease. Hepatology 55, 1809-1819. doi: 10.1002/hep. 25536

Ren, F. H., Yang, H., He, R. Q., Lu, J. N., Lin, X. G., Liang, H. W., et al. (2018). Analysis of microarrays of miR-34a and its identification of prospective target gene signature in hepatocellular carcinoma. BMC Cancer 18:12. doi: 10.1186/s12885-017-3941-x

Rong, M., He, R., Dang, Y., and Chen, G. (2014). Expression and clinicopathological significance of miR-146a in hepatocellular carcinoma tissues. Ups. J. Med. Sci. 119, 19-24. doi: 10.3109/03009734.2013.856970

Roscigno, G., Puoti, I., Giordano, I., Donnarumma, E., Russo, V., Affinito, A., et al. (2017). MiR-24 induces chemotherapy resistance and hypoxic advantage in breast cancer. Oncotarget 8, 19507-19521. doi: 10.18632/oncotarget.14470

Schoolmeesters, A., Eklund, T., Leake, D., Vermeulen, A., Smith, Q., Force Aldred, S., et al. (2009). Functional profiling reveals critical role for miRNA in differentiation of human mesenchymal stem cells. PLOS ONE 4:e5605. doi: 10.1371/journal.pone.0005605

Schraivogel, D., Weinmann, L., Beier, D., Tabatabai, G., Eichner, A., Zhu, J. Y., et al. (2011). CAMTA1 is a novel tumour suppressor regulated by miR-9/9* in glioblastoma stem cells. EMBO J. 30, 4309-4322. doi: 10.1038/emboj.2 011.301

Shaalan, Y. M., Handoussa, H., Youness, R. A., Assal, R. A., El-Khatib, A. H., Linscheid, M. W., et al. (2018). Destabilizing the interplay between miR-1275 and IGF2BPs by Tamarix articulata and quercetin in hepatocellular carcinoma. Nat. Prod. Res. 32, 2217-2220. doi: 10.1080/14786419.2017.1366478

Shariff, M. I., Cox, I. J., Gomaa, A. I., Khan, S. A., Gedroyc, W., and Taylor-Robinson, S. D. (2009). Hepatocellular carcinoma: current trends in worldwide epidemiology, risk factors, diagnosis and therapeutics. Expert Rev. Gastroenterol. Hepatol. 3, 353-367. doi: 10.1586/egh.09.35

Shen, J., Wang, S., Zhang, Y. J., Kappil, M. A., Chen Wu, H., Kibriya, M. G., et al. (2012). Genome-wide aberrant DNA methylation of microRNA host genes in hepatocellular carcinoma. Epigenetics 7, 1230-1237. doi: 10.4161/epi.22140

Shen, S., Lin, Y., Yuan, X., Shen, L., Chen, J., Chen, L., et al. (2016). Biomarker MicroRNAs for diagnosis, prognosis and treatment of hepatocellular carcinoma: a functional survey and comparison. Sci. Rep. 6:38311. doi: 10.1038/srep38311

Shi, W., Zhang, Z., Yang, B., Guo, H., Jing, L., Liu, T., et al. (2017). Overexpression of microRNA let-7 correlates with disease progression and poor prognosis in hepatocellular carcinoma. Medicine 96, e7764-e7764. doi: 10.1097/MD.0000000000007764

Shimono, Y., Mukohyama, J., Nakamura, S., and Minami, H. (2015). MicroRNA regulation of human breast cancer stem cells. J. Clin. Med. 5:E2. doi: $10.3390 / \mathrm{jcm} 5010002$
Shimono, Y., Zabala, M., Cho, R. W., Lobo, N., Dalerba, P., Qian, D., et al. (2009). Downregulation of miRNA-200c links breast cancer stem cells with normal stem cells. Cell 138, 592-603. doi: 10.1016/j.cell.2009.07.011

Skårn, M., Namløs, H. M., Noordhuis, P., Wang, M. Y., Meza-Zepeda, L. A., Myklebost, O., et al. (2012). Adipocyte differentiation of human bone marrowderived stromal cells is modulated by microRNA-155, microRNA-221, and microRNA-222. Stem Cells Dev. 21, 873-883. doi: 10.1089/scd.2010.0503

Song, B., Wang, Y., Titmus, M. A., Botchkina, G., Formentini, A., Kornmann, M., et al. (2010). Molecular mechanism of chemoresistance by miR-215 in osteosarcoma and colon cancer cells. Mol. Cancer 9:96. doi: 10.1186/1476-4598-9-96

Song, J., Ouyang, Y., Che, J., Li, X., Zhao, Y., Yang, K., et al. (2017). Potential value of miR-221/222 as diagnostic, prognostic, and therapeutic biomarkers for diseases. Front. Immunol. 8:56. doi: 10.3389/fimmu.2017.00056

Stadler, B., Ivanovska, I., Mehta, K., Song, S., Nelson, A., Tan, Y., et al. (2010). Characterization of microRNAs involved in embryonic stem cell states. Stem Cells Dev. 19, 935-950. doi: 10.1089/scd.2009.0426

Su, H., Yang, J. R., Xu, T., Huang, J., Xu, L., Yuan, Y., et al. (2009). MicroRNA-101, down-regulated in hepatocellular carcinoma, promotes apoptosis and suppresses tumorigenicity. Cancer Res. 69, 1135-1142. doi: 10.1158/0008-5472.CAN-08-2886

Sun, C., Yao, X., Jiang, Q., and Sun, X. (2018). miR-106b targets DAB2 to promote hepatocellular carcinoma cell proliferation and metastasis. Oncol. Lett. 16, 3063-3069. doi: 10.3892/ol.2018.8970

Sun, F., Wang, J., Pan, Q., Yu, Y., Zhang, Y., Wan, Y., et al. (2009). Characterization of function and regulation of miR-24-1 and miR-31. Biochem. Biophys. Res. Commun. 380, 660-665. doi: 10.1016/j.bbrc.2009.01.161

Sun, T. Y., Xie, H. J., Li, Z., Kong, L. F., Gou, X. N., Li, D. J., et al. (2017). miR34a regulates HDAC1 expression to affect the proliferation and apoptosis of hepatocellular carcinoma. Am. J. Transl. Res. 9, 103-114.

Sun, X., Liu, J., Xu, C., Tang, S. C., and Ren, H. (2016). The insights of Let-7 miRNAs in oncogenesis and stem cell potency. J. Cell. Mol. Med. 20, 1779-1788. doi: $10.1111 / \mathrm{jcmm} .12861$

Sun, Z., Han, Q., Zhou, N., Wang, S., Lu, S., Bai, C., et al. (2013). MicroRNA-9 enhances migration and invasion through KLF17 in hepatocellular carcinoma. Mol. Oncol. 7, 884-894. doi: 10.1016/j.molonc.2013.04.007

Sung, S. Y., Liao, C. H., Wu, H. P., Hsiao, W. C., Wu, I. H., Jinpu, et al. (2013). Loss of let-7 microRNA upregulates IL-6 in bone marrow-derived mesenchymal stem cells triggering a reactive stromal response to prostate cancer. PLoS ONE 8:e71637. doi: 10.1371/journal.pone.0071637

Szotek, P. P., Pieretti-Vanmarcke, R., Masiakos, P. T., Dinulescu, D. M., Connolly, D., Foster, R., et al. (2006). Ovarian cancer side population defines cells with stem cell-like characteristics and Mullerian Inhibiting Substance responsiveness. Proc. Natl. Acad. Sci. U.S.A. 103, 11154-11159. doi: 10.1073/pnas.0603672103

Takahashi, R.-,u., Miyazaki, H., and Ochiya, T. (2014). The role of microRNAs in the regulation of cancer stem cells. Front. Genet. 4:295. doi: 10.3389/fgene.2013.00295

Takata, A., Otsuka, M., Yoshikawa, T., Kishikawa, T., Ohno, M., and Koike, K. (2013). MicroRNAs and liver function. Minerva Gastroenterol. Dietol. $59,187-203$

Tan, Y., Ge, G., Pan, T., Wen, D., Chen, L., Yu, X., et al. (2014). A serum microRNA panel as potential biomarkers for hepatocellular carcinoma related with hepatitis B virus. PLoS ONE 9:e107986. doi: 10.1371/journal.pone.0107986

Tang, H. (2013). miR-10a regulates epithelial-mesenchymal transition and adhesion and angiogenesis in hepatoma. FASEB J. 27(1_supple), lb153-lb153. doi: 10.1371/journal.pone.0064273

Tang, T., Yang, Z., Zhu, Q., Wu, Y., Sun, K., Alahdal, M., et al. (2018). Upregulation of miR-210 induced by a hypoxic microenvironment promotes breast cancer stem cell metastasis, proliferation, and self-renewal by targeting E-cadherin. FASEB J. 32, 6965-6981. doi: 10.1096/fj.201801013R

Tao, J., Jiang, L., and Chen, X. (2018). Roles of micro RNA in liver cancer. Liver Res. 2, 61-72. doi: 10.1016/j.livres.2018.06.002

Taube, J. H., Malouf, G. G., Lu, E., Sphyris, N., Vijay, V., Ramachandran, P. P., et al. (2013). Epigenetic silencing of microRNA-203 is required for EMT and cancer stem cell properties. Sci. Rep. 3:2687. doi: 10.1038/srep02687

Thurnherr, T., Mah, W. C., Lei, Z., Jin, Y., Rozen, S. G., and Lee, C. G. (2016). Differentially expressed miRNAs in hepatocellular carcinoma target genes in 
the genetic information processing and metabolism pathways. Sci. Rep. 6:20065. doi: $10.1038 /$ srep20065

Tong, Y., Xu, W., Han, H., Chen, Y., Yang, J., Qiao, H., et al. (2011). Tanshinone IIA increases recruitment of bone marrow mesenchymal stem cells to infarct region via up-regulating stromal cell-derived factor-1/CXC chemokine receptor 4 axis in a myocardial ischemia model. Phytomedicine 18, 443-450. doi: 10.1016/j.phymed.2010.10.009

Tsai, S. C., Lin, C. C., Shih, T. C., Tseng, R. J., Yu, M. C., Lin, Y. J., et al. (2017). The miR-200b-ZEB1 circuit regulates diverse stemness of human hepatocellular carcinoma. Mol. Carcinog. 56, 2035-2047. doi: 10.1002/mc.22657

Tsang, F. H., Au, V., Lu, W. J., Shek, F. H., Liu, A. M., Luk, J. M., et al. (2014). Prognostic marker microRNA-125b inhibits tumorigenic properties of hepatocellular carcinoma cells via suppressing tumorigenic molecule eIF5A2. Dig. Dis. Sci. 59, 2477-2487. doi: 10.1007/s10620-014-3184-5

Tu, H., Wei, G., Cai, Q., Chen, X., Sun, Z., Cheng, C., et al. (2015). MicroRNA212 inhibits hepatocellular carcinoma cell proliferation and induces apoptosis by targeting FOXA1. Onco. Targets. Ther. 8, 2227-2235. doi: 10.2147/OTT. S87976

Turchi, L., Debruyne, D. N., Almairac, F., Virolle, V., Fareh, M., Neirijnck, Y., et al. (2013). Tumorigenic potential of miR-18A* in Glioma initiating cells requires NOTCH-1 signaling. Stem Cells. 31, 1252-1265. doi: 10.1002/stem.1373

Ullmann, P., Nurmik, M., Schmitz, M., Rodriguez, F., Weiler, J., Qureshi-Baig, K., et al. (2019). Tumor suppressor miR-215 counteracts hypoxiainduced colon cancer stem cell activity. Cancer Lett. 450, 32-41. doi: 10.1016/j.canlet.2019.02.030

Valeri, N., Vannini, I., Fanini, F., Calore, F., Adair, B., and Fabbri, M. (2009). Epigenetics, miRNAs, and human cancer: a new chapter in human gene regulation. Mamm Genome. 20, 573-580. doi: 10.1007/s00335-009-9206-5

Wahid, F., Shehzad, A., Khan, T., and Kim, Y. Y. (2010). MicroRNAs: synthesis, mechanism, function, and recent clinical trials. Biochim. Biophys. Acta. 1803, 1231-1243. doi: 10.1016/j.bbamcr.2010.06.013

Wang, C., Wang, X., Su, Z., Fei, H., Liu, X., Pan, Q., et al. (2015). MiR-25 promotes hepatocellular carcinoma cell growth, migration and invasion by inhibiting RhoGDI1. Oncotarget 6, 36231-36244. doi: 10.18632/oncotarget.4740

Wang, J., Li, J., Wang, X., Zheng, C., and Ma, W. (2013). Downregulation of microRNA-214 and overexpression of FGFR-1 contribute to hepatocellular carcinoma metastasis. Biochem. Biophys. Res. Commun. 439, 47-53. doi: 10.1016/j.bbrc.2013.08.032

Wang, L.-J., He, C. C., Sui, X., Cai, M. J., Zhou, C. Y., Ma, J. L., et al. (2015). MiR-21 promotes intrahepatic cholangiocarcinoma proliferation and growth in vitro and in vivo by targeting PTPN14 and PTE. Oncotarget 6, 5932-5946. doi: 10.18632/oncotarget.3465

Wang, M., Zhang, J., Tong, L., Ma, X., and Qiu, X. (2015). MiR-195 is a key negative regulator of hepatocellular carcinoma metastasis by targeting FGF2 and VEGFA. Int. J. Clin. Exp. Pathol. 8, 14110-14120.

Wang, M., Zhao, J., Zhang, L., Wei, F., Lian, Y., Wu, Y., et al. (2017). Role of tumor microenvironment in tumorigenesis. J. Cancer. 8, 761-773. doi: $10.7150 /$ jca. 17648

Wang, S., Yin, J., Li, T., Yuan, L., Wang, D., He, J., et al. (2015). Upregulated circulating miR-150 is associated with the risk of intrahepatic cholangiocarcinoma. Oncol. Rep. 33, 819-825. doi: 10.3892/or.2014.3641

Wang, W. Y., Zhang, H. F., Wang, L., Ma, Y. P., Gao, F., Zhang, S. J., et al. (2014). miR-21 expression predicts prognosis in hepatocellular carcinoma. Clin. Res. Hepatol. Gastroenterol. 38, 715-719. doi: 10.1016/j.clinre.2014.07.001

Wang, X., Zhang, W., Sun, X., Lin, Y., and Chen W. (2018). Cancerassociated fibroblasts induce epithelial-mesenchymal transition through secreted cytokines in endometrial cancer cells. Oncol. Lett. 15, 5694-5702. doi: 10.3892/ol.2018.8000

Wang, Y., Fan, H., Zhao, G., Liu, D., Du, L., Wang, Z., et al. (2012). miR-16 inhibits the proliferation and angiogenesis-regulating potential of mesenchymal stem cells in severe pre-eclampsia. FEBS J. 279, 4510-4524. doi: 10.1111/febs.12037

Wang, Y., Lee, A. T., Ma, J. Z., Wang, J., Ren, J., Yang, Y., et al. (2008). Profiling microRNA expression in hepatocellular carcinoma reveals microRNA-224 upregulation and apoptosis inhibitor-5 as a microRNA-224-specific target. J. Biol. Chem. 283, 13205-13215. doi: 10.1074/jbc.M707629200

Wei, W., Wanjun, L., Hui, S., Dongyue, C., Xinjun, Y., Jisheng, Z., et al. (2013). miR-203 inhibits proliferation of HCC cells by targeting survivin. Cell Biochem. Funct. 31, 82-85. doi: 10.1002/cbf.2863
Wei, X., Tan, C., Tang, C., Ren, G., Xiang, T., Qiu, Z., et al. (2013). Epigenetic repression of miR-132 expression by the hepatitis $\mathrm{B}$ virus $\mathrm{x}$ protein in hepatitis B virus-related hepatocellular carcinoma. Cell. Signal. 25, 1037-1043. doi: 10.1016/j.cellsig.2013.01.019

Wheeler, B. M., Heimberg, A. M., Moy, V. N., Sperling, E. A., Holstein, T. W., Heber, S., et al. (2009). The deep evolution of metazoan microRNAs. Evol. Dev. 11, 50-68. doi: 10.1111/j.1525-142X.2008.00302.x

White, D. L., Kanwal, F., and El-Serag, H. B. (2012). Association between nonalcoholic fatty liver disease and risk for hepatocellular cancer, based on systematic review. Clin. Gastroenterol. Hepatol. 10, 1342-1359. e2. doi: $10.1016 /$ j.cgh.2012.10.001

Whiteside, T. (2008). The tumor microenvironment and its role in promoting tumor growth. Oncogene 27:5904-5912. doi: 10.1038/onc.2008.271

Wong, Q. W., Lung, R. W., Law, P. T., Lai, P. B., Chan, K. Y., To, K. F., et al. (2008). MicroRNA-223 is commonly repressed in hepatocellular carcinoma and potentiates expression of Stathmin1. Gastroenterology. 135, 257-269. doi: 10.1053/j.gastro.2008.04.003

Xia, C., Shui, L., Lou, G., Ye, B., Zhu, W., Wang, J., et al. (2017). 0404 inhibits hepatocellular carcinoma through a p53/miR-34a/SIRT1 positive feedback loop. Sci. Rep. 7:4396. doi: 10.1038/s41598-017-04487-x

Xie, D., Yuan, P., Wang, D., Jin, H., and Chen, H. (2017). Expression and prognostic significance of miR-375 and miR-221 in liver cancer. Oncol. Lett. 14, 2305-2309. doi: 10.3892/ol.2017.6423

Xie, F., Yuan, Y., Xie, L., Ran, P., Xiang, X., Huang, Q., et al. (2017). miRNA-320a inhibits tumor proliferation and invasion by targeting cMyc in human hepatocellular carcinoma. Onco. Targets. Ther. 10, 885-894. doi: 10.2147/OTT.S122992

Xie, Y., Yao, Q., Butt, A. M., Guo, J., Tian, Z., Bao, X., et al. (2014). Expression profiling of serum microRNA-101 in HBV-associated chronic hepatitis, liver cirrhosis, and hepatocellular carcinoma. Cancer Biol. Ther. 15, 1248-1255. doi: $10.4161 /$ cbt.29688

Xiong, Y., Fang, J. H., Yun, J. P., Yang, J., Zhang, Y., Jia, W. H., et al. (2010). Effects of MicroRNA-29 on apoptosis, tumorigenicity, and prognosis of hepatocellular carcinoma. Hepatology 51, 836-845. doi: 10.1002/hep.23380

Xu, C., Ren, G., Cao, G., Chen, Q., Shou, P., Zheng, C., et al. (2013). miR155 regulates immune modulatory properties of mesenchymal stem cells by targeting TAK1-binding protein 2. J. Biol. Chem. 288, 11074-11079. doi: $10.1074 /$ jbc.M112.414862

Xu, J., Kang, Y., Liao, W. M., and Yu, L. (2012). MiR-194 regulates chondrogenic differentiation of human adipose-derived stem cells by targeting Sox5. PLoS ONE 7:e31861. doi: 10.1371/journal.pone.0031861

Xu, Q., Zhang, M., Tu, J., Pang, L., Cai, W., and Liu, X. (2015). MicroRNA-122 affects cell aggressiveness and apoptosis by targeting PKM2 in human hepatocellular carcinoma. Oncol. Rep. 34, 2054-2064. doi: 10.3892/or.2015.4175

Xu, W., Ji, J., Xu, Y., Liu, Y., Shi, L., Liu, Y., et al. (2015). MicroRNA-191, by promoting the EMT and increasing CSC-like properties, is involved in neoplastic and metastatic properties of transformed human bronchial epithelial cells. Mol. Carc. 54 (Suppl. 1), E148-E161. doi: 10.1002/mc.22221

Xu, X. L., Xing, B. C., Han, H. B., Zhao, W., Hu, M. H., Xu, Z. L., et al. (2009). The properties of tumor-initiating cells from a hepatocellular carcinoma patient's primary and recurrent tumor. Carcinogenesis 31, 167-174. doi: 10.1093/carcin/bgp232

Xu, Y., An, Y., Wang, Y., Zhang, C., Zhang, H., Huang, C., et al. (2013). miR-101 inhibits autophagy and enhances cisplatin-induced apoptosis in hepatocellular carcinoma cells. Oncol. Rep. 29, 2019-2024. doi: 10.3892/or.2013.2338

Xu, Y., Bu, X., Dai, C., and Shang, C. (2015). High serum microRNA122 level is independently associated with higher overall survival rate in hepatocellular carcinoma patients. Tumor Biol. 36, 4773-4776. doi: 10.1007/s13277-015-3128-5

Yacoub, R. A., Fawzy, I. O., Assal, R. A., Hosny, K. A., Zekri, A. N., Esmat, G., et al. (2016). miR-34a: multiple opposing targets and one destiny in hepatocellular carcinoma. J. Clin. Transl. Hepatol. 4, 300-305. doi: 10.14218/JCTH.2016.0 0031

Yan, J. J., Zhang, Y. N., Liao, J. Z., Ke, K. P., Chang, Y., Li, P. Y., et al. (2015). MiR-497 suppresses angiogenesis and metastasis of hepatocellular carcinoma by inhibiting VEGFA and AEG-1. Oncotarget 6, 29527-29542. doi: 10.18632/oncotarget.5012 
Yang, F., Zhang, L., Wang, F., Wang, Y., Huo, X. S., Yin, Y. X., et al. (2011). Modulation of the unfolded protein response is the core of microRNA-122involved sensitivity to chemotherapy in hepatocellular carcinoma. Neoplasia 13, 590-600. doi: 10.1593/neo.11422

Yang, H., Cho, M. E., Li, T. W., Peng, H., Ko, K. S., Mato, J. M., et al. (2013). MicroRNAs regulate methionine adenosyltransferase 1A expression in hepatocellular carcinoma. J. Clin. Invest. 123, 285-298. doi: 10.1172/JCI63861

Yang, J. D., and Roberts, L. R. (2010). Epidemiology and management of hepatocellular carcinoma. Infect. Dis. Clin. North Am. 24, 899-919. doi: 10.1016/j.idc.2010.07.004

Yang, Y., Zhang, J., Xia, T., Li, G., Tian, T., Wang, M., et al. (2016). MicroRNA210 promotes cancer angiogenesis by targeting fibroblast growth factor receptor-like 1 in hepatocellular carcinoma. Oncol. Rep. 36, 2553-2562. doi: 10.3892/or.2016.5129

Yata, K., Beder, L. B., Tamagawa, S., Hotomi, M., Hirohashi, Y., Grenman, R., et al. (2015). MicroRNA expression profiles of cancer stem cells in head and neck squamous cell carcinoma. Int. J. Oncol. 47, 1249-1256. doi: 10.3892/ijo.2015.3145

Yin, J., Hou, P., Wu, Z., Wang, T., and Nie, Y. (2015). Circulating miR-375 and miR-199a-3p as potential biomarkers for the diagnosis of hepatocellular carcinoma. Tumor Biol. 36, 4501-4507. doi: 10.1007/s13277-015-3092-0

Youness, R. A., El-Tayebi, H. M., Assal, R. A., Hosny, K., Esmat, G., and Abdelaziz, A. I. (2016). MicroRNA-486-5p enhances hepatocellular carcinoma tumor suppression through repression of IGF-1R and its downstream mTOR, STAT3 and c-Myc. Oncol. Lett. 12, 2567-2573. doi: 10.3892/ol.2016.4914

Yu, F., Lu, Z., Chen, B., Dong, P., and Zheng, J. (2015). microRNA-150: a promising novel biomarker for hepatitis B virus-related hepatocellular carcinoma. Diagn. Pathol. 10:129. doi: 10.1186/s13000-015-0369-y

Yu, L., Gong, X., Sun, L., Zhou, Q., Lu, B., Zhu, L., et al. (2016). The circular RNA Cdrlas act as an oncogene in hepatocellular carcinoma through targeting miR-7 expression. PLoS ONE 11:e0158347. doi: 10.1371/journal.pone.0158347

Yu, Y., Nangia-Makker, P., Farhana, L., G., Rajendra, S., Levi, E., Majumdar, A. P., et al. (2015). miR-21 and miR-145 cooperation in regulation of colon cancer stem cells. Mol. Cancer. 14:98. doi: 10.1186/s12943-015-0372-7

Yu, Z., Lin, X., Tian, M., and Chang, W. (2018). microRNA196b promotes cell migration and invasion by targeting FOXP2 in hepatocellular carcinoma. Oncol. Rep. 39, 731-738. doi: 10.3892/or.2017.6130

Yunqiao, L., Vanke, H., Jun, X., and Tangmeng, G. (2014). MicroRNA-206, down-regulated in hepatocellular carcinoma, suppresses cell proliferation and promotes apoptosis. Hepatogastroenterology 61, 1302-1307.

Zhang, H., Cai, K., Wang, J., Wang, X., Cheng, K., Shi, F., et al. (2014). MiR7, inhibited indirectly by lincRNA HOTAIR, directly inhibits SETDB1 and reverses the EMT of breast cancer stem cells by downregulating the STAT3 pathway. Stem Cells. 32, 2858-2868. doi: 10.1002/stem.1795

Zhang, J. F., Fu, W. M., He, M. L., Xie, W. D., Lv, Q., Wan, G., et al. (2011). MiRNA20 a promotes osteogenic differentiation of human mesenchymal stem cells by co-regulating BMP signaling. RNA Biol. 8, 829-838. doi: 10.4161/rna.8.5.16043

Zhang, L., Huang, J., Yang, N., Greshock, J., Megraw, M. S., Giannakakis, A., et al. (2006). microRNAs exhibit high frequency genomic alterations in human cancer. Proc. Natl. Acad. Sci. U.S.A. 103:9136. doi: 10.1073/pnas.0508889103
Zhang, W. C., Chin, T. M., Yang, H., Nga, M. E., Lunny, D. P., Lim, E. K., et al. (2016). Tumour-initiating cell-specific miR-1246 and miR-1290 expression converge to promote non-small cell lung cancer progression. Nat. Commun. 7:11702. doi: $10.1038 /$ ncomms 11702

Zhang, Y., Guo, X., Xiong, L., Kong, X., Xu, Y., Liu, C., et al. (2012). MicroRNA101 suppresses SOX9-dependent tumorigenicity and promotes favorable prognosis of human hepatocellular carcinoma. FEBS Lett. 586, 4362-4370. doi: 10.1016/j.febslet.2012.10.053

Zhao, Y., Jia, H. L., Zhou, H. J., Dong, Q. Z., Fu, L. Y., Yan, Z. W., et al. (2009). [Identification of metastasis-related microRNAs of hepatocellular carcinoma in hepatocellular carcinoma cell lines by quantitative real time PCR]. Zhonghua Gan Zang Bing Za Zhi. 17, 526-530.

Zheng, J., Dong, P., Gao, S., Wang, N., and Yu, F. (2013). High expression of serum miR-17-5p associated with poor prognosis in patients with hepatocellular carcinoma. Hepatogastroenterology 60, 549-552. doi: 10.5754/hge 12754

Zhou, C., Liu, J., Li, Y., Liu, L., Zhang, X., Ma, C. Y., et al. (2011). microRNA$1274 \mathrm{a}$, a modulator of sorafenib induced a disintegrin and metalloproteinase 9 (ADAM9) down-regulation in hepatocellular carcinoma. FEBS Lett. 585, 1828-1834. doi: 10.1016/j.febslet.2011.04.040

Zhou, J., Lu, S., Yang, S., Chen, H., Shi, H., Miao, M., et al. (2014). MicroRNA127 post-transcriptionally downregulates Sept7 and suppresses cell growth in hepatocellular carcinoma cells. Cell. Physiol. Biochem. 33, 1537-1546. doi: 10.1159/000358717

Zhou, J., Yu, L., Gao, X., Hu, J., Wang, J., Dai, Z., et al. (2011). Plasma microRNA panel to diagnose hepatitis B virus-related hepatocellular carcinoma. J. Clin. Oncol. 29, 4781-4788. doi: 10.1200/JCO.2011.38.2697

Zhou, X., Yue, Y., Wang, R., Gong, B., and Duan, Z. (2017). MicroRNA-145 inhibits tumorigenesis and invasion of cervical cancer stem cells. Int. J. Oncol. 50, 853-862. doi: 10.3892/ijo.2017.3857

Zhu, H. T., Dong, Q. Z., Sheng, Y. Y., Wei, J. W., Wang, G., Zhou, H. J., et al. (2012). MicroRNA-29a-5p is a novel predictor for early recurrence of hepatitis B virusrelated hepatocellular carcinoma after surgical resection. PLoS ONE 7:e52393. doi: 10.1371/journal.pone.0052393

Zhu, Q., Gong, L., Wang, J., Tu, Q., Yao, L., Zhang, J. R., et al. (2016). miR-10b exerts oncogenic activity in human hepatocellular carcinoma cells by targeting expression of CUB and sushi multiple domains 1 (CSMD1). BMC Cancer 16, 806-806. doi: 10.1186/s12885-016-2801-4

Conflict of Interest: The authors declare that the research was conducted in the absence of any commercial or financial relationships that could be construed as a potential conflict of interest.

Copyright (C) 2019 Nasr, Salah, Abd Elkodous, Elshenawy and El-Badri. This is an open-access article distributed under the terms of the Creative Commons Attribution License (CC BY). The use, distribution or reproduction in other forums is permitted, provided the original author(s) and the copyright owner(s) are credited and that the original publication in this journal is cited, in accordance with accepted academic practice. No use, distribution or reproduction is permitted which does not comply with these terms. 